Development of an Ultrasonic Process for Detoxifying Groundwater and Soil: Laboratory Research

Annual Report for Fiscal Year 1991

Energy Systems Division

Argonne National Laboratory

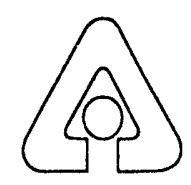

Operated by The University of Chicago,

under Contract W-31-109-Eng-38, for this

United States Department of Energy 


\section{Argonne National Laboratory}

Argonne National Laboratory, with facilities in the states of Illinois and Idaho, is owned by the United States government, and operated by the University of Chicago under the provisions of a contract with the Department of Energy.

This technical memo is a product of Argonne's Energy Systems (ES)

Division. For information on the division's scientific and engineering activities, contact:

Director, Energy Systems Division

Argonne National Laboratory

Argonne, Illinois 60439-4815

Telephone (708) 252-3724

Presented in this technical memo are preliminary results of ongoing work or work that is more limited in scope and depth than that described in formal reports issued by the ES Division.

\section{Disclaimer}

This report was prepared as an account of work sponsored by an agency of the United States Govemment. Neither the United States Govemment nor any agency thereof, nor any of their employees, makes any warranty, express or implied, or assumes any $\mathrm{s}$ al liability or responsibility for the accuracy, completeness, or usefulness of any information, apparatus, product, or process disclosed, or represents that its use would not infringe privately owned rights. Reference herein to any specific commercial product, process, or senvice by trade name, trademark, manufacturer, or otherwise, does not necessarily constitute or imply its endorsement, recommendation, or favoring by the United States Govemment or any agency thereof. The views and opinions of authors expressed herein do not necessarily state or reflect those of the United States Govemment or any agency thereof.

Reproduced directly from the best available copy.

Available to DOE and DOE contractors from the Office of Scientific and Technical Information, P.O. Box 62, Oak Ridge, TN 37831; prices available from (615) 576-8401.

Available to the public from the National Technical Information Service, U.S. Department of Commerce, 5285 Port Royal Road, Springfield, VA 22161. 


\section{Development of an Ultrasonic Process for Detoxifying Groundwater and Soil: Laboratory Research}

\section{Annual Report for Fiscal Year 1991}

by J.M. Wu, H.S. Huang, and C.D. Livengood

Energy Systems Division,

Argonne National Laboratory, 9700 South Cass Avenue, Argonne, Illinois 60439

January 1992

Work sponsored by United States Department of Energy,

Assistant Secretary for Environmental Restoration and Waste Management, Office of Technology Development 


\section{Contents}

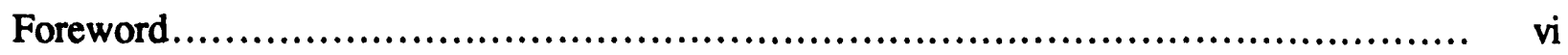

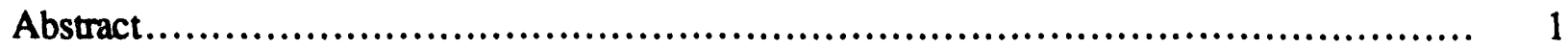

1 Introduction............................................................................ 1

1.1 Background........................................................................ 2

1.2 The Illtrasonic Detoxification Process ...................................... 2

1.3 Report Organization............................................................. 3

2 Laboratory Research.................................................................... 5

2.1 Experimental Apparatus ........................................................ 5

2.1.1 Ultrasonic Power Supply .......................................... 5

2.1.2 Processing Cell ...................................................... 7

2.1.3 Temperature-Controlling Bath........................................ 7

2.2 Experimental Materials............................................................. 7

2.3 Analytical Methods............................................................... 8

2.4 Safety and Other Considerations ............................................ 8

2.5 Experimental Procedure .................................................. 9

3 Experimental Results and Discussion .......................................... 11

3.1 Effect of Sonication Time........................................................ 11

3.2 Effect of Steady-State Operating Temperature..................................... 12

3.3 Effect of Power Intensity .................................................. 13

3.4 Effect of Initial pH Value...................................................... 19

3.5 Effect of Oxidant Addition ...................................................... 19

4 Development of Reaction Model ........................................................ 23

4.1 Detailed Chemical Mechanism .......................................................... 23

4.2 Development of Mathematical Model ................................................ 24

4.3 Computer Simulation and Results ....................................... 25

5 Conclusions and Recommendations............................................ 28

5.1 Conclusions......................................................................... 28

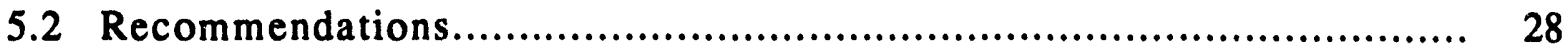

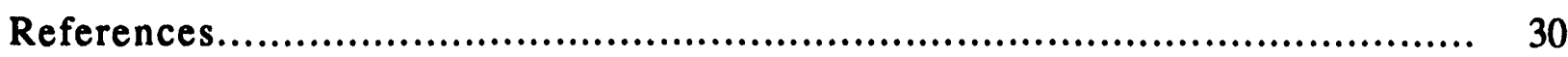

Appendix: Procedures for Starting Up and Shutting Down an Experiment ................ 33 
Figures

1.1 Schematic of Ultrasonic Groundwater-Detoxification Process................................. 4

2.1 Experimental Apparatus....................................................... 5

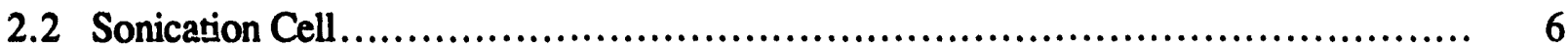

3.1 Decrease in $\mathrm{CCl}_{4}$ Concentration vs. Sonication Period at a $\mathrm{CCl}_{4}$ Concentration

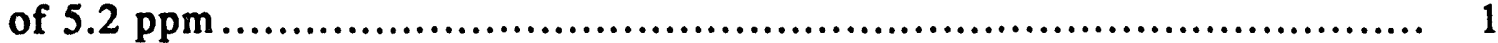

3.2 Decrease in $\mathrm{CCl}_{4}$ Concentration vs. Sonication Period at a $\mathrm{CCl}_{4}$ Concentration of $130 \mathrm{ppm}$

3.3 Decrease in $\mathrm{CCl}_{4}$ Concentration vs. Sonication Period at a $\mathrm{CCl}_{4}$ Concentration of $47 \mathrm{ppm}$

3.4 Decreases in $\mathrm{CCl}_{4}$ Concentration vs. Sonication Period at $\mathrm{CCl}_{4}$ Concentrations of $8 \mathrm{ppm}, 1.6 \mathrm{ppm}$, and $0.53 \mathrm{ppm}$.

3.5 First-Order Plot of Natural $\mathrm{Log}$ of $\mathrm{CCl}_{4}$ Concentration vs. Sonication Period 16

3.6 Effect of Steady-State Temperature on $\mathrm{CCl}_{4}$ Sonication 17

3.7 Effect of Power Intensity on $\mathrm{CCl}_{4}$ Sonication 17

3.8 Dependence of $\mathrm{CCl}_{4}$ Destruction Rate on Power Intensity 18

3.9 Effect of Initial $\mathrm{pH}$ Value on $\mathrm{CCl}_{4}$ Sonication

3.10 Effect of $\mathrm{H}_{2} \mathrm{O}_{2}$ Dosage on $\mathrm{CCl}_{4}$ Sonication

3.11 Effect of $\mathrm{H}_{2} \mathrm{O}_{2}$ Dosage on $\mathrm{CCl}_{4}$ with No Sonication

4.1 Experimental Data vs. Calculated Results of Model at $\mathrm{CCl}_{4}$ Concentrations of $8 \mathrm{ppm}$ and $1.6 \mathrm{ppm}$.

4.2 Experimental Data vs. Calculated Results of Model at a $\mathrm{CCl}_{4}$ Concentration of $47 \mathrm{ppm}$ 


\section{Tables}

3.1 Oxidation Potential and Relative Oxidation Power of Hydroxyl Radical and Other Oxidants

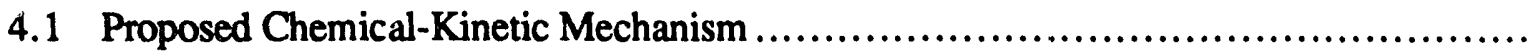

24 


\section{Foreword}

This report presents the results of laboratory research conducted during FY 1991 as part of the project "Ultrasonic Process for Detoxifying Groundwater and Soil." That project is being carried out at Argonne National Laboratory for the U.S. Department of Energy, Office of Technology Development, to further the development of an innovative process for the effective and economic destruction of chlorinated organic compounds in grolindwater and soil. Other project tasks include (1) process development activities designed to acquire engineering data and develop process designs in anticipation of large-scale field tests of the concept and (2) technical support activities that encompass reporting and technology-transfer efforts. 


\title{
Development of an Ultrasonic Process for Detoxifying Groundwater and Soil: Laboratory Research
}

\author{
by
}

\author{
J.M. Wu, H.S. Huang, and C.D. Livengood
}

\begin{abstract}
Argonne National Laboratory is conducting laboratory research to study the effectiveness of a new technique in which ultrasonic energy is used to convert chlorinated organic compounds into nonhazardous end products. Destruction efficiencies of greater than $99 \%$ were achieved for the organic compounds in aqueous solution. Key process parameters, such as solution $\mathrm{pH}$ values, steadystate temperatures under operating conditions, ultrasonic-power intensities, and oxidant concentrations, were investigated. In addition, a detailed chemical-kinetic mechanism for the destruction of the organic compounds under an ultrasonic field was developed and incorporated into a computational model. The agreement between the model and experimental results is generally good.
\end{abstract}

\section{Introduction}

The objective of this project is to develop and demonstrate an innovative process for the effective destruction of low concentrations of chlorinated organic compounds in soil and groundwater. The process involves the use of intense ultrasonic-energy waves that transform the chlorinated organic compounds into nonhazardous end products. The technical feasibility of the concept was demonstrated approximately twenty years ago for the destruction of phenols in wastewater from industrial facilities and recently by researchers using small batch-processing units for the destruction of polychlorinated biphenyls (PCBs) in soil and sludges. During the earlier small-scale tests, no systematic experiments were conducted on the destruction of low concentrations of chlorinated organic compounds.

The important reaction mechanisms in the process are not well understood; moreover, the engineering data needed $\mathrm{fcr}$ the design of a cominercial-scale continuous-flow facility are not available. Preliminary cost estimates, however, indicate that the technology for ultrasonic detoxification is less expensive than incineration for the treatment of soils and sludges contaminated with PCBs. Furthermore, the technology may be more reliable and generate fewer secondary environmental emissions than conventional technology. When fully developed, this technology will provide a cost-effective alternative for detoxifying soils and groundwater and reducing the amount of waste produced during the remediation of U.S. Department of Energy (DOE) sites. 


\subsection{Background}

Hazardous chemical wastes have been generated in the United States for over a century, and radioactive mixed wastes have been generated for over forty years. Before the promulgation of applicable regulations for the treatment and disposal of solid waste, man-made hazardous and/or mixed wastes were disposed of in landfills, buried, or dumped into sewers, streams, or oceans. Growing concerns about the effects of waste on terrestrial and aquatic ecosystems have prompted the U.S. government and private companies to begin to develop technologies for improving the management of the large amount of new hazardous and mixed wastes generated, as well as for cleaning up existing (active and inactive) contaminated sites.

The contamination of groundwater and soil with chlorinated organic compounds has been identified as a critical problem at many DOE sites. The most common contaminants are carbon tetrachloride $\left(\mathrm{CCl}_{4}\right)$ and trichloroethylene (TCE), both of which are hazardous components as defined in the Resource Conservation and Recovery Act (RCRA). Other organic compounds used at DOE sites that may have contaminated soil and groundwater include nonvolatile and soluble organic compounds (extractants and complexing agents) and insoluble organic compounds (PCBs and pesticides); some of these compounds are also RCRA hazardous components. These sites cannot be restored or delisted without adequate treatment of the groundwater and soil.

Commercial technologies for treating soils contaminated with organic compounds include incineration and soil-gas extraction by the application of vacuum, steam, or forced air. However, incineration is an energy-intensive process for low-concentration, organic-compound-contaminated soils, and it may generate secondary pollutants. Soil-gas extraction is restricted to volatile organic compounds and by the time required for the complete removal of organic compounds from a specific site. Other technologies under development for the treatment of contaminated soil include radio-frequency heating, electro-osmosis, supercritical water oxidation of excavated soils, soil washing, in-situ or ex-situ biotreatment, and in-situ vitrification (EPA 1990).

Commercial technologies for treating groundwater contaminated with organic compounds include pumping/stripping and pumping/carbon adsorption. Both technologies, however, produce undesirable waste streams that require additional treatment to destroy the organic contaminants. Other technologies under development for the treatment of contaminated groundwater include in-situ biological (e.g., research and development under way at Pacific Northwest Laboratory and Oak Ridge National Laboratory) and in-situ chemical treatment, ex-situ chemical treatment (e.g., wet-air oxidation, supercritical water oxidation, catalytic destruction), solar/photon destruction, and surface biotreatment (EPA 1990).

\subsection{The Ultrasonic Detoxification Process}

Ultrasonic irradiation is one promising process for the treatment of liquid and aqueous hazardous wastes. In this process, ultrasonic energy (high-frequency sound) waves produce an 
alternating adiabatic compression and rarefaction (expansion) of the liquid media being irradiated. Compression cycles exert a positive pressure on the liquid, pushing the molecules together, while expansion cycles exert a negative pressure, pulling the molecules away from one another. During the expansion cycle, a sound wave of sufficient intensity can generate cavities, which grow gradually with the expansion and compression cycles. When a critical size is attained, the final compression part of the wave violently collapses the cavities, creating extremely high local temperatures (up to 5,000 K) and high local pressures (up to 500 atmospheres) (Suslick 1988, 1989, and 1990). Under such conditions, water decomposes into extremely reactive hydroxyl radicals $(\mathrm{OH})$ and hydrogen atoms $(\mathrm{H})$. During the subsequent cooling phase, the hydrogen atoms and hydroxyl radicals can recombine to form hydrogen peroxide $\left(\mathrm{H}_{2} \mathrm{O}_{2}\right)$ and molecular hydrogen. If organic compounds are present in the water, they are rapidly destroyed in this environment. Inorganic compounds, in contrast, can be either oxidized or reduced. The intensity of cavity implosion, and hence the nature of the reactions involved, can be controlled by such process parameters as ultrasonic frequency, ultrasonic intensity per volume of liquid medium, static pressure, choice of liquid, and choice of ambient gas (Suslick 1988, 1989, and 1990).

The use of ultrasonic energy to promote chemical reactions has been investigated for many years. Thus, the literature contains many references to different types of reactions that have been promoted by ultrasonic energy, including syntheses of a variety of organic compounds, polymerization, and cleavage of aliphatic and aromatic molecules. The application of ultrasonic irradiation to the treatment of hazardous chlorinated organic wastes started in the early 1980s. A U.S. patent was granted in 1984 for a process by which halogenated aromatic substances (e.g., PCBs) were detoxified by means of ultrasonic energy (Suslick 1988). Results reported in this patent and in subsequent tests in which small batch reactors with PCB-contaminated oils and soil samples were used showed destruction efficiencies varying from $60 \%$ to greater than $99 \%$. In these prior tests, no systematic testing was conducted on chlorinated organic compounds other than PCBs.

Figure 1.1 is a conceptual flow sheet for a process to treat groundwater that is based on ultrasonic detoxification. The contaminated groundwater is directed into the ultrasonic irradiation chamber, which is sized to provide a sufficient residence time to obtain the desired destruction efficiency for the contaminants. After treatment, the cleaned water can be reinjected into the ground. For the treatment of soils contaminated with chlorinated organic compounds, additional unit operations (such as soil preparation, soil-water slurrying, and dewatering) will be required.

\subsection{Report Organization}

The experimental part of the project consists of two main tasks: laboratory research and process development. The laboratory research is intended to improve our understanding of the process kinetics and to identify novel process variations/concepts. This work is being carried out at Argonnr. National Laboratory (ANL). The process development effort involves the systematic acquisitio'. of the engineering data required to scale up the process from the bench scale to the 


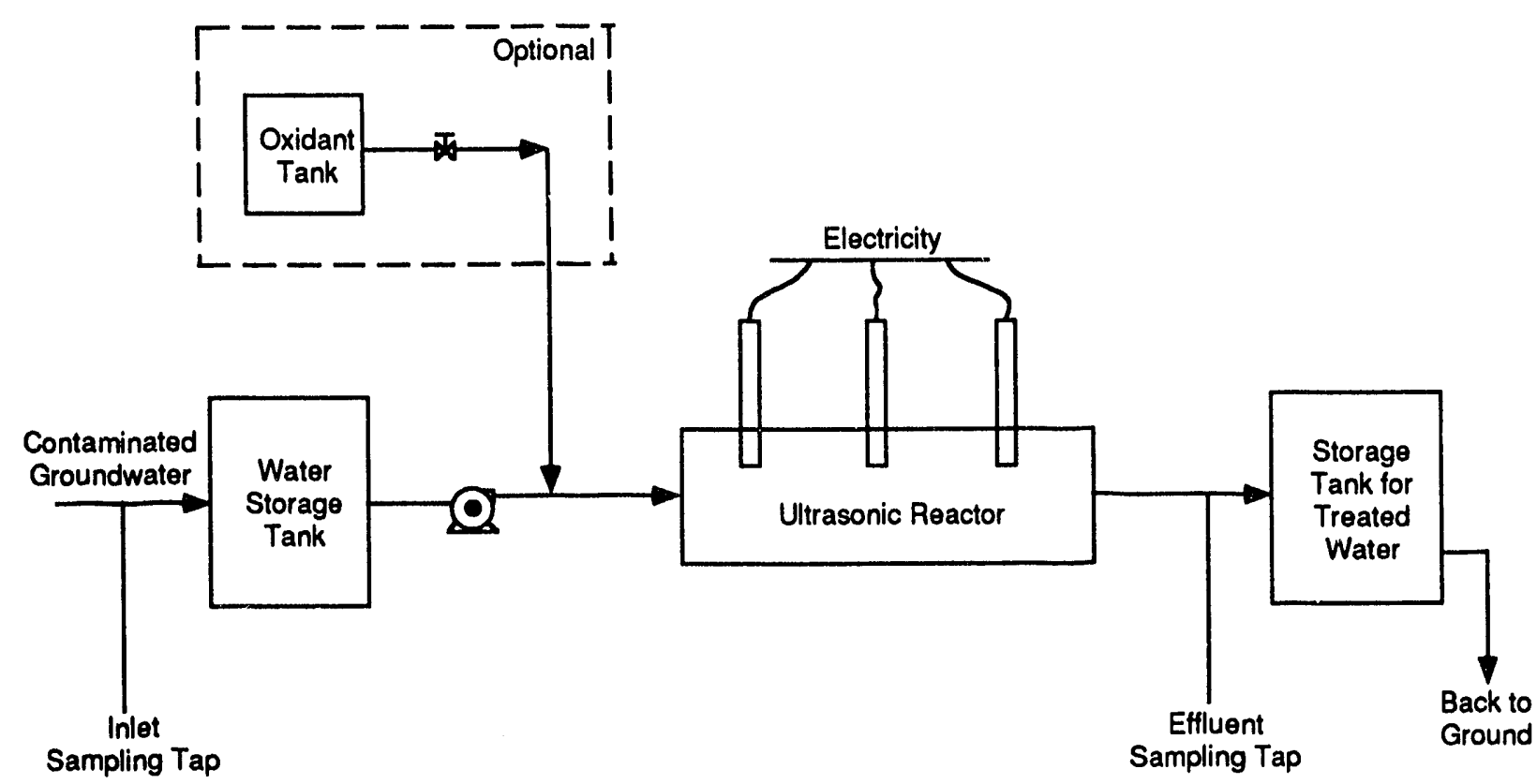

FIGURE 1.1 Schematic of Ultrasonic Groundwater-Detoxification Process

demonstration phase and to perform engineering and economic evaluations of the process. This work has been conducted largely at Trinity Environmental Technologies, Inc. (TET), of Mound Valley, Kansas, through a subcontract to ANL. This report presents only the results from the laboratory research effort conducted at ANL. A companion repori containing the results from the process development study will be prepared separately.

The remainder of this report is organized into four sections. Section 2 describes the laboratory apparatus used in the experiments. Results from the experiments are given in Section 3, and the development of a reaction model for the destruction of the contaminant in the water phase is described in Section 4. Finally, Section 5 presents the conclusions drawn as a result of the laboratory experiments and provides recommendations for further laboratory research. 


\section{Laboratory Research}

\subsection{Experimental Apparatus}

The initial configuration of the experimental sonication apparatus was designed for the investigation of process kinetics for the destruction of chlorinated organic compounds and other RCRA components in groundwater. The major apparatus principally consisted of an ultrasonic power supply with a generator/converter and probe, a processing cell, and a temperaturecontrolling bath. For environmental and safety considerations, most of these components were located inside a well-ventilated hood. A diagram of the apparatus is shown in Figure 2.1, and a close-up of a typical processing cell is shown in Figure 2.2.

\subsubsection{Uitrasonic Power Supply}

The ultrasonic power supply (Sonics \& Materials, VC 600) transformed line voltage of $50-60 \mathrm{~Hz}$ to a frequency as high as $20 \mathrm{kHz}(20,000 \mathrm{cycles} / \mathrm{s})$. This high-frequency electrical energy was transmitted to the piezoelectric transducer within the converter, where it was changed to mechanical vibrations. The proportion of electric energy converted, ranging from 0 to $600 \mathrm{~W}$, was adjustable and could be monitored through the output controller on the control panel, which was located on the front of the power supply. To optimize the performance of the power supply, it was tuned to the converter/probe assembly. For safety, a minimum reading (usually less than 20

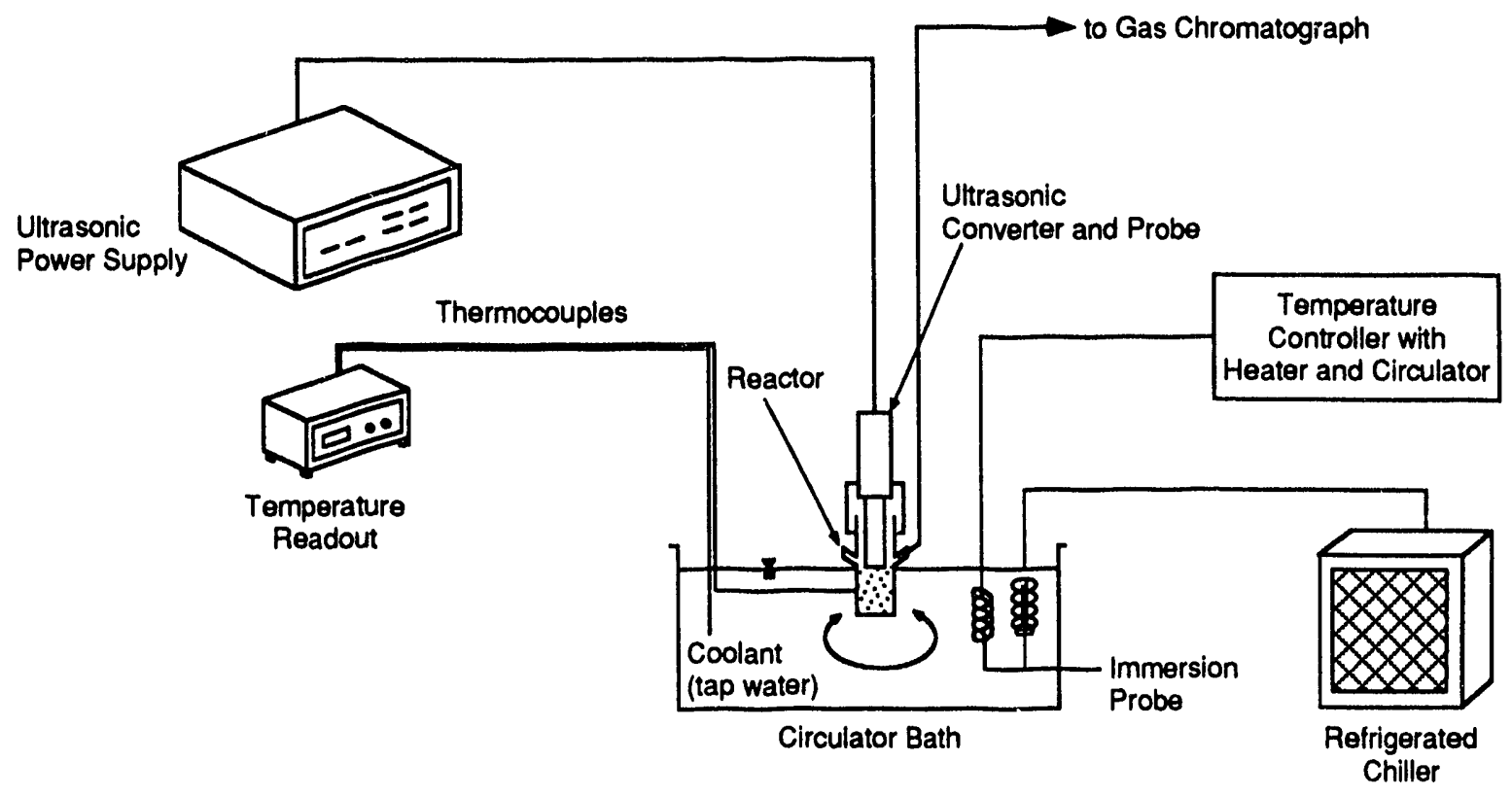

FIGURE 2.1 Experimental Apparatus 


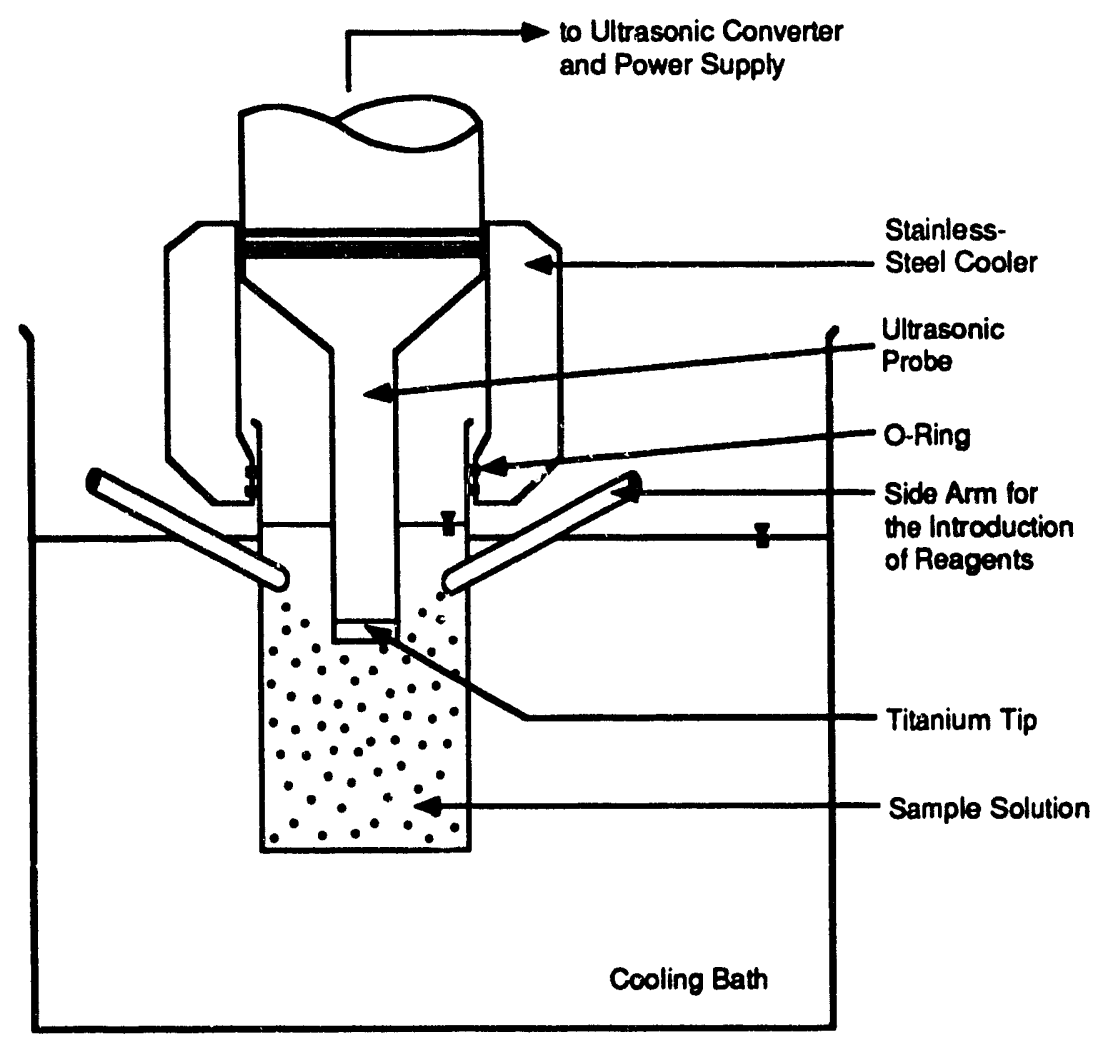

FIGURE 2.2 Sonication Cell

on the power monitor) was consistently held and recorded. If an unusual reading was observed (usually higher than the minimum reading), the probe, tip, or accessories could have been loose or out of resonance, and maintenance was necessary.

The mechanical vibrations generated by the converter were intensified by the probe, creating pressure waves delivered to the medium through a titanium tip. The power intensity at the titanium tip, therefore, was capable of reaching $500 \mathrm{~W} / \mathrm{cm}^{2}$, compared with about $1 \mathrm{~W} / \mathrm{cm}^{2}$ for an ultrasonic cleaning bath.

An alternate ultrasonic power supply (Sonics \& Materials, VC 60) was used to study the effect of power intensity on the destruction of organic compounds. The major improvement with this apparatus was the addition of a wattmeter, which displayed the actual, instantaneous ultrasonic power delivered into the sample solution. With the use of this apparatus, converter and probe losses were automatically deducted so that the effect of power intensity could be accurately investigated. 


\subsubsection{Processing Cell}

The sonication processing cell, as shown in Figure 2.2, was a borosilicate glass cell with a stainless-steel collar. The collar could be screwed onto the hom of the ultrasonic probe so that the probe could be immersed into the sample solution as sonication proceeded. The reaction vessel had side arms so that the chemical reagents (such as $\mathrm{H}_{2} \mathrm{O}_{2}$, which served as an oxidant in the subsequent experiments) could be introduced into the reactor and gas samples could be directed to a gas-analysis system. Before the experiments began, the reaction vessel was immersed in a constant-temperature bath. The temperature inside the reaction vessel was kept relatively constant by cool water that circulated in the constant-temperature bath, and the vessel was continuously monitored by means of a thermocouple probe and temperature readout.

For high-temperature experiments $\left(>35^{\circ} \mathrm{C}\right)$, sonication was conducted in a stainless-steel sealed reactor. This $50-\mathrm{mL}$ sealed accessory had two ports located above the liquid level, and these ports permitted the capture of evaporated gases and volatilized organic vapors that were released as a result of the high tempera.ture during the experiment. The reactor was also constructed for safe ultrasonic treatment at the high pressures (up to $100 \mathrm{psi}$ [ $7 \mathrm{bar}$ ) that might be generated during irradiation at high temperature.

\subsection{Temperature-Controlling Bath}

The temperature-controlling system consisted of a 12-L-capacity circulator bath (Haake, model D1) with a heater/refrigerator (Cole-Parmer, model 01283-70) and temperature sensor that maintained the desired temperature. A powerful circulator pump ensured a uniform bath temperature. According to the manufacturer's information, this system could maintain a temperature ranging from -10 to $100^{\circ} \mathrm{C}$; tap water or silicone oil (if necessary) was used as coolant, and the temperature could be decreased to $-50^{\circ} \mathrm{C}$ by applying a refrigerated chiller. The accuracy of the temperature control was $\pm 0.2^{\circ} \mathrm{C}$. If the temperature went too high (beyond $130^{\circ} \mathrm{C}$ ), the power of the system would cut off automatically, thereby preventing injury to the operator and damage to the circulator bath. The cutoff circuit was independent of the primary control system, so if the electronic controls failed, the safety system would still shut off the power.

\subsection{Experimental Materials}

Carbon tetrachloride $\left(\mathrm{CCl}_{4}\right)$, sulfuric acid (certified ACS grade, Mallinckrodt, Inc.), hydrogen peroxide ( $30 \%$, analytical grade, Mallinckrodt, Inc.), and n-hexane (certified for trace environmental analysis by capillary gas chromatography and gas chromatography-mass spectrometry, Bardick \& Jackson) were used as received from the suppliers. To remove trace impurities, sodium sulfate (certified ACS grade, Mallinckrodt, Inc.) was washed with n-hexane and dried overnight in an oven $\left(104^{\circ} \mathrm{C}\right)$ before use. The materials were stored in completely labeled bottles that were placed inside a well-ventilated hood. 
A standard $\mathrm{CCl}_{4}$ solution was prepared by stirring the neat liquid (gas chromatography purity $\mathbf{2 9 9 . 9 \% ) ~ l i q u i d ~ w i t h ~ l a b o r a t o r y ~ d e i o n i z e d ~ w a t e r ~ o v e r n i g h t . ~ T h e ~ s o l u t i o n ~ w a s ~ t h e n ~}$ equilibrated for at least $24 \mathrm{~h}$ in a screw-capped glass container (saturated concentration of $\mathrm{CCl}_{4}$ at room temperature was assumed to be $800 \mathrm{mg} / \mathrm{L}$ ). This standard solution was then used to prepare all of the sample solutions for the subsequent experiments.

\subsection{Analytical Methods}

Analyses of organic compound concentrations in the early experiments (those kinetic studies with initial concentrations of $\mathrm{CCl}_{4}$ higher than $10 \mathrm{mg} / \mathrm{L}$ ) were carried out by using a gas chromatograph (GC) (Gao-Mac 750P) with a flame ionization detector (FID). A 6-in. glass column packed with a 80/120 Carbopack B/3\%, SP-1500 stabilizer was used after it had been conditioned at $230^{\circ} \mathrm{C}$ for more than $15 \mathrm{~h}$. Immediately after the experiment, a $1-\mu \mathrm{L}$ sample solution was directly injected into the GC and analyzed so that the organic compounds would not be volatilized. Because of the detection limits of the $\mathrm{FID}, \mathrm{CCl}_{4}$ concentrations lower than $5 \mathrm{mg} / \mathrm{L}$ were not easily detected by this method.

An alternative GC (Varian 3700) equipped with an electronic capture detector (ECD) was then used for the analysis of chlorinated organic compounds in subsequent experiments. The ECD is much more sensitive to chlorinated organic compounds than the FID; therefore, lower concentrations of these compounds were detectable. A 10-in. stainless-steel column with the same packing as previously used in the Gao-Mac 750P was employed. Sample solutions were prepared by following the U.S. Environmental Protection Agency's (EPA's) recommended procedures for analyzing chlorinated hydrocarbons by gas chromatography (Federal Register 1979). Immediately after the experiment, irradiated sample solutions were extracted by using $n$-hexane and dehydrated by using sodium sulfate before analysis. Because the solutions were considered to be sufficiently clean for the GC analysis, no additional cleanup procedures to remove impurities in the analyzing solutions were needed.

The $\mathrm{pH}$ value of the sample solution in the $\mathrm{pH}$-effect study was determined by using a Cole-Parmer Chemcadet $\mathrm{pH} / \mathrm{ion} / \mathrm{mV}$ meter (model 5986-50) that was calibrated before use with

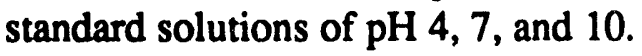

\subsection{Safety and Other Considerations}

Laboratory safety was a primary concern in the setup of the experimental facility and in the performance of the sonication experiments. The principal chemical material used in the experiment $\left(\mathrm{CCl}_{4}\right)$ as a major contaminant is a colorless, highly volatile organic compound, which could be adsorbed through skin, cause irritation, and represent a cancer risk under exposure $(2.7 \mu \mathrm{g} / \mathrm{L}$ of $\mathrm{CCl}_{4}$ is estimated by the U.S. EPA to pose a cancer risk equivalent to $10^{-5}$ per uccurrence). Concentrations of $2,000 \mathrm{ppm}$ by volume and above can result in a severe toxic effect within 
$60 \mathrm{~min}$ in humans who lack proper protection. At concentrations higher than $50 \mathrm{mg} / \mathrm{L}, \mathrm{CCl}_{4}$ has an ether-like odor, which makes it detectable by smell.

In addition to safety concerns about $\mathrm{CCl}_{4}$, we were concerned about suspected intermediate products, such as hexachloroethane $\left(\mathrm{CCl}_{3} \mathrm{CCl}_{3}\right)$ and perchloroethylene $\left(\mathrm{CCl}_{2} \mathrm{CCl}_{2}\right)$, possibly generaied in the sonication process. The noise produced by harmonics emanating from the vessel walls and the fluid surface during sonication was also of concern early in the experimental process, but the noise level was subsequently determined to be acceptable and safe for the operator.

All components of the experimental apparatus, excluding the power supply, were installed in a ventilated hood. The gases volatilized from the organic compounds (or produced as a result of the breakdown of these compounds) were continuously vented and exhausted. The transparent window of the hood provided double protection, thereby preventing the released gases from reaching the operator.

After the whole system was assembled, it was tested to ensure that the components and assemblies functioned as designed. Fifteen milliliters of laboratory deionized water was used as the sample solution, placed in a glass processing cell, and irradiated for $60 \mathrm{~min}$, which was much longer than the estimated sonication time for the subsequent experiments. The test results were satisfactory, and the components functioned normally.

Although we considered our arrangement capable of reliably controlling the temperature of the cooling water and irradiated solution, temperature readouts and thermocouples were used to ensure that the temperatures were within the desired range for each experiment. For hightemperature experiments, such as those higher than $35^{\circ} \mathrm{C}$, the glass processing cell was replaced with a stainless-steel reactor. The stainless-steel reactor not only provided us with a leak-proof chamber with which we could eliminate the volatilization of organic compounds at high temperature, but it also gave us a pressure-resistant environment for safe operation. According to the manufacturer, the stainless-steel reactor can withstand a total pressure of up to $100 \mathrm{psi}$ (7 bar), which is much higher than the calculated operating pressure that could be reached during the experiments.

\subsection{Experimental Procedure}

Because $\mathrm{CCl}_{4}$ has been identified as a highly volatile, toxic organic compound, and because it may be fatal or represent a cancer risk if it is swallowed, inhaled, or absorbed through skin, proper protective equipment (such as gloves, safety eyeglasses, and laboratory coat) should be worn during an experiment in which $\mathrm{CCl}_{4}$ is used. In addition, all of the experiments should be operated in a ventilated hood to prevent the release of toxic gases. 
On the basis of safety considerations and experimental objectives, a detailed experimental procedure was developed for the operation of this apparatus. The procedure, provided in full in Appendix $\mathrm{A}$, is summarized here.

Temperature was one of the primary controlling parameters for the experiment. Prior to irradiation, cooling water in the temperature-controlling bath was circulated until a desired temperature was reached and maintained. A $15-\mathrm{mL}$ sample solution, which was diluted from the standard $\mathrm{CCl}_{4}$ stock solution, was prepared for each experiment. If necessary, the $\mathrm{pH}$ valiue of the sample soiution was adjusted and measured. This solution was then carefully transferred to the processing cell and irradiated for a desired period. The irradiation time was preselected and accurately programmed to ensure repeatability. The intensity of the power that was delivered to the solution was regulated $b_{j}$ ' adjusting the controller on the power supply panel. The temperatures inside and outside the processing cell were continuously monitored throughout the experiment.

After each sonication experiment, the processing cell was cooled to $25^{\circ} \mathrm{C}$ to eliminate temperature effects (e.g., the different organic vapor pressures generated in the reactor at different temperatures). Then, a 10-mL sample solution was withdrawn and extracted with $n$-hexane. After the extraction, the solution was dehydrated by using sodium sulfate and stored in a sampling bottle sealed with Teflon ${ }^{\mathrm{TM}}$ for future treatment or analysis. A calibration curve based on aqueous samples of known $\mathrm{CCl}_{4}$ concentrations was developed by using the same extraction/dehydration protocol. This curve was rechecked before each experiment and routinely confirmed during the analyses.

Upon the conclusion of the experiments, the cooling water was kept circulating until it reached room temperature, and then the water was drained and the main power was turned off. 


\section{Experimental Results and Discussion}

\subsection{Effect of Sonication Time}

The first series of experiments was conducted to demonstrate the technical feasibility of destroying low concentrations of $\mathrm{CCl}_{4}$ under ultrasonic irradiation. The operating temperature was $25^{\circ} \mathrm{C}$, and the initial concentrations of $\mathrm{CCl}_{4}$ were varied from 4 to $10 \mathrm{mg} / \mathrm{L}$, approximating typical conditions for contaminated groundwater. The irradiated sample solutions were sent to the Argonne Analytical Chemistry Laboratory (ACL) where they were analyzed by using a GC/MS system equipped with a purge and trap sample-conditioning subsystem. A typical result is shown in Figure 3.1. The concentration of $\mathrm{CCl}_{4}$ decreased exponentically with an increase in sonication time; within 10 min of sonication, the concentration of $\mathrm{CCl}_{4}$ dropped to about $12 \mu \mathrm{g} / \mathrm{L}$, and in $15 \mathrm{~min}$, it dropped to an undetectable level (2 ppb). Because the removal efficiency of $\mathrm{CCl}_{4}$ was calculated to be greater than $99.5 \%$ in $10 \mathrm{~min}$ through this process, sonication appears to be feasible for the removal of $\mathrm{CCl}_{4}$ from water.

To further verify the feasibility and study the reaction kinetics for organic compounds in an ultrasonic field, more experiments were performed with various initial concentrations of $\mathrm{CCl}_{4}$, ranging from low $(<5 \mathrm{mg} / \mathrm{L})$ to high $(>100 \mathrm{mg} / \mathrm{L})$. Again, the experimental temperature was maintained at $25^{\circ} \mathrm{C}$. Irradiated water samples were analyzed by using the methods described in Section 2.3. The results were in excellent agreement with those previously obtained and analyzed in the ACL. Upon exposure of $\mathrm{CCl}_{4}$ solutions to ultrasound in the presence of dissolved air, the $\mathrm{CCl}_{4}$ in the solutions decreased. Greater than $99 \%$ removal efficiency of the $\mathrm{CCl}_{4}$ was achieved in the experiments. Figures 3.2-3.4 show plots of $\mathrm{CCl}_{4}$ concentration versus sonication time at various initial $\mathrm{CCl}_{4}$ concentrations. For initial $\mathrm{CCl}_{4}$ concentrations as high as $130 \mathrm{ppm}$ (Figure 3.2), the residual concentration decreased to about $5 \mathrm{ppm}$ after $5 \mathrm{~min}$ of irradiation, while for an initial $\mathrm{CCl}_{4}$ concentration of $1.6 \mathrm{ppm}$ (Figure 3.4), the residual concentration decreased to about $0.05 \mathrm{ppm}$ within the same irradiation period. The concentration of $\mathrm{CCl}_{4}$ decreased exponentially with sonication period. At higher initial $\mathrm{CCl}_{4}$ concentrations within the same sonication period, greater amounts of $\mathrm{CCl}_{4}$ decreased; however, the destruction efficiency was about the same.

First-order plots of the natural $\log$ of $\mathrm{CCl}_{4}$ concentration versus sonication period for various initial $\mathrm{CCl}_{4}$ concentrations are shown in Figure 3.5. The ultrasonic degradation of $\mathrm{CCl}_{4}$ apparently follows first-order kinetics within the current experimental concentration range. An average first-order rate constant of $k=0.7 \mathrm{~min}^{-1}$ was determined on the basis of the slopes of these plots. Chen, Chang, and Smith (1969) reported that at low concentrations, the destruction of organic compounds should follow a first-order reaction, but at higher concentrations, the destruction of organic compounds should become a zero-order reaction. 


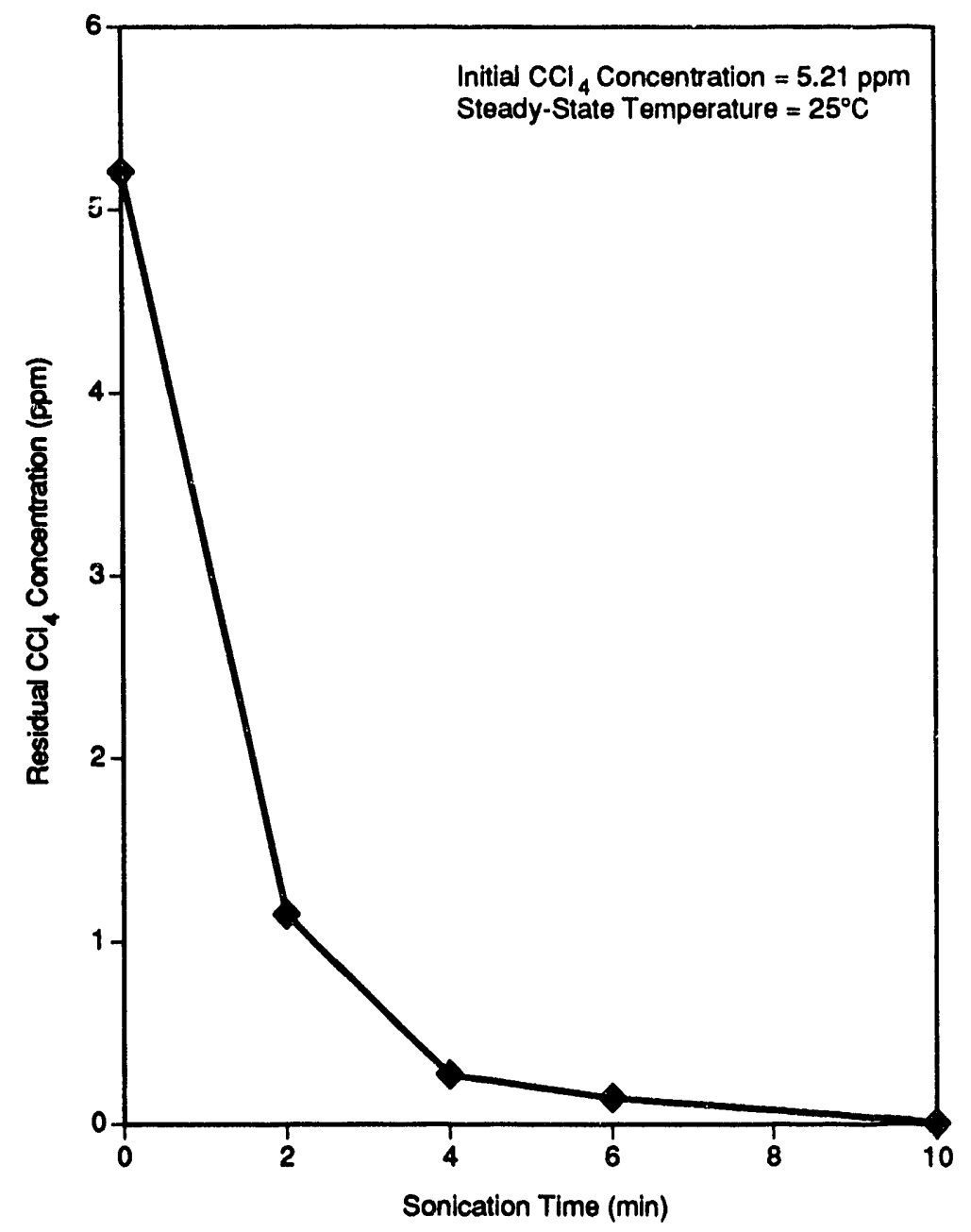

FIGURE 3.1 Decrease in $\mathrm{CCl}_{4}$ Concentration vs. Sonication Period at a $\mathrm{CCl}_{4}$ Concentration of $5.2 \mathrm{ppm}$

\subsection{Effect of Steady-State Operating Temperature}

The temperature in the reaction vessel was an important factor in maintaining a high destruction rate of organic compounds in the solution. Chen and Kalback (1967) have reported that in sonochemistry, one should not attempt reactions in a solvent (here, water) that is near its boiling point $\left(100^{\circ} \mathrm{C}\right)$, because the rarefaction cycle causes the water to boil as a result of the reduced pressure generated. Consequently, any cavitation holes, or cavities, that are formed will fill with water vapor almost instantaneously. The water vapor could reduce the extremes of temperature and pressure generated, thus decreasing the direct destruction efficiency of the organic compounds. On the other hand, the secondary reactions occurring in the liquid phase may be enhanced by operating the system at higher temperatures. 


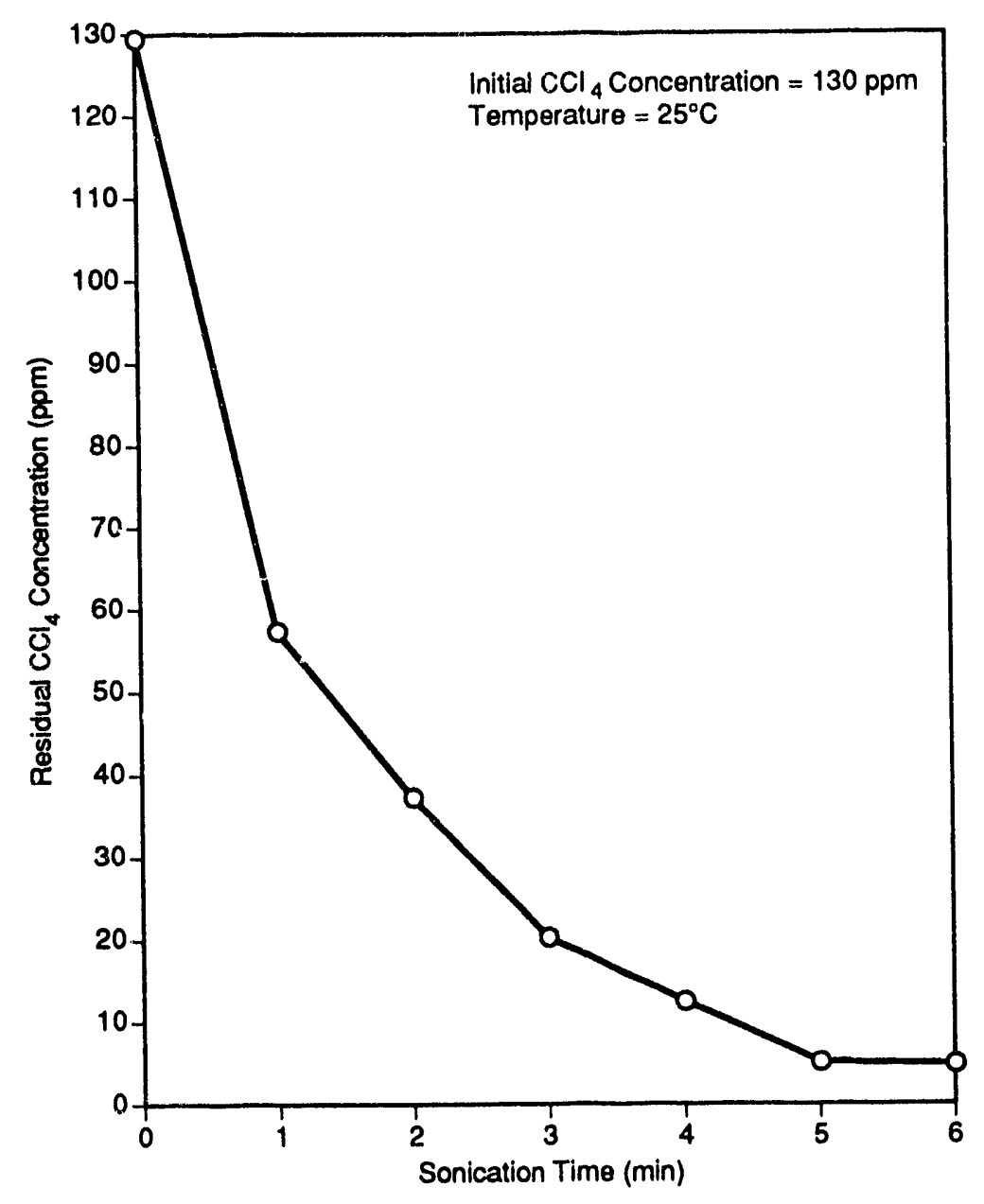

FIGURE 3.2 Decrease in $\mathrm{CCl}_{4}$ Concentration vs. Sonication Period at a $\mathrm{CCl}_{4}$ Concentration of $130 \mathrm{ppm}$

The effect of a steady-state temperature on the destruction efficiency of $\mathrm{CCl}_{4}$ is shown in Figure 3.6. A removal efficiency of about $80 \%$ was observed for $4 \mathrm{~min}$ of irradiation; the removal efficiency remained unchanged within a temperature range of $20-60^{\circ} \mathrm{C}$. These results illustrate that, within this temperature range, increasing the steady-state temperature of the irradiation solutions seems to have little effect on $\mathrm{CCl}_{4}$ destruction efficiency. In other words, operating the system in the optimal temperature range will yield high removal efficiencies within reasonable operation times.

\subsection{Effect of Power Intensity}

Ultrasonic power intensity is also an important factor affecting the destruction rate of organic compounds. In general, it has been reported (Chen and Kalback 1967) that destruction 


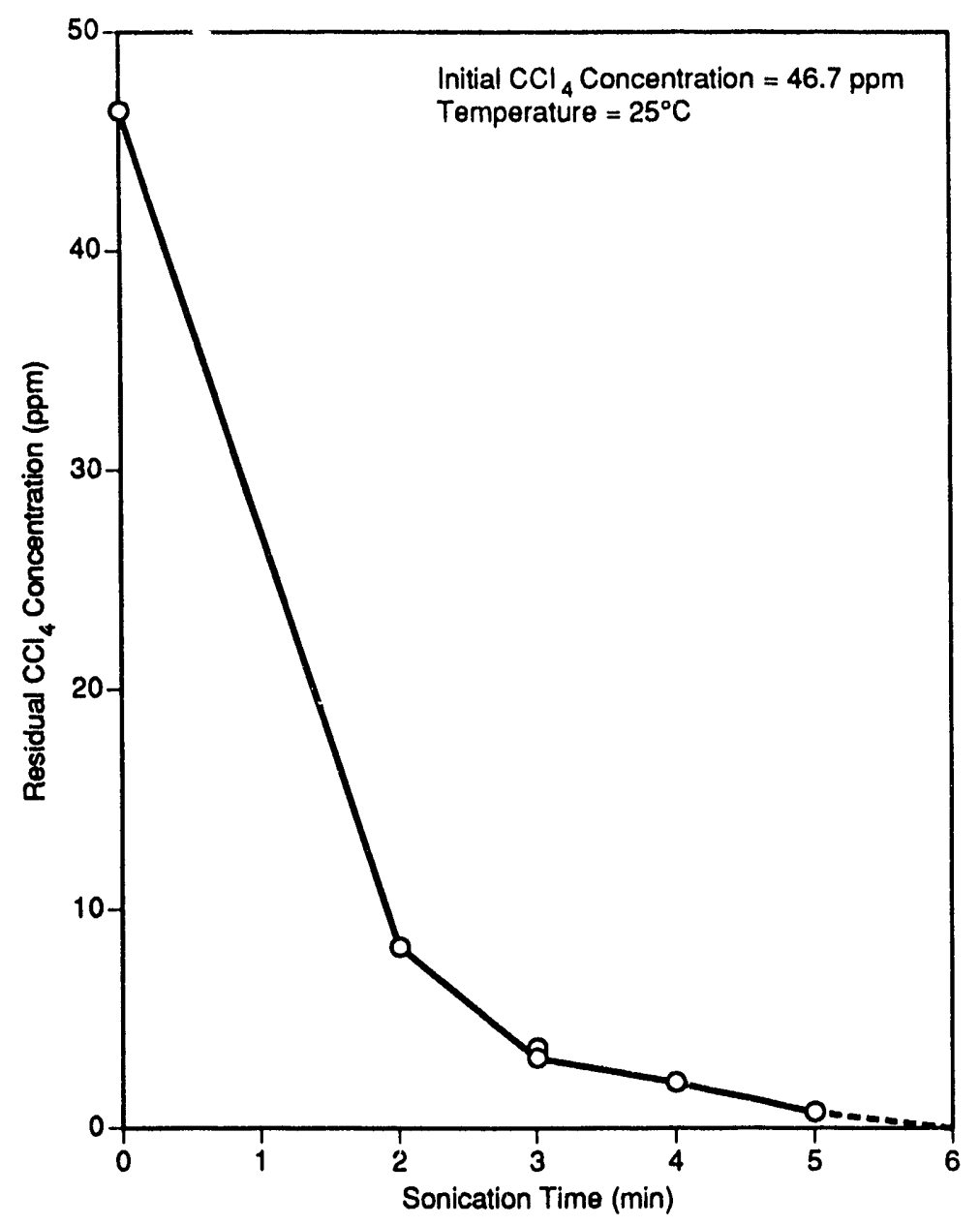

FIGURE 3.3 Decrease in $\mathrm{CCl}_{4}$ Concentration vs. Sonication Period at a $\mathrm{CCl}_{4}$ Concentration of $47 \mathrm{ppm}$

commences when the applied intensity is above a critical level, and any increase in intensity will increase the sonochemical effect. However, it must be realized that intensity cannot be increased indefinitely (Rozenberg 1965; Fogler and Barnes 1968). With an increase in power intensity, the cavities may grow so large during rarefaction that the time available for their collapse is insufficient, and therefore, the effective coupling of the ultrasonic energy to the system is reduced (Mason 1990).

Figure 3.7 shows the effect of power intensity on the destruction of $\mathrm{CCl}_{4}$. After $1 \mathrm{~min}$ of irradiation, residual $\mathrm{CCl}_{4}$ decreases with increasing power intensity. $\mathrm{More}^{\mathrm{CCl}_{4}}$ molecules are destroyed at higher power intensities. The $\mathrm{CCl}_{4}$ destruction rate versus power intensity is shown in Figure 3.8. Within the current experimental range, the destruction rate seems to have a linear relationship to the power intensity. Although threshold intensity was not experimentally determined, it is estimated to be lower than the $0.9 \mathrm{~W} / \mathrm{cm}^{2}$ shown in Figure 3.8. The destruction rate would be negligible if the power delivered into the solution were lower than the threshold intensity. 

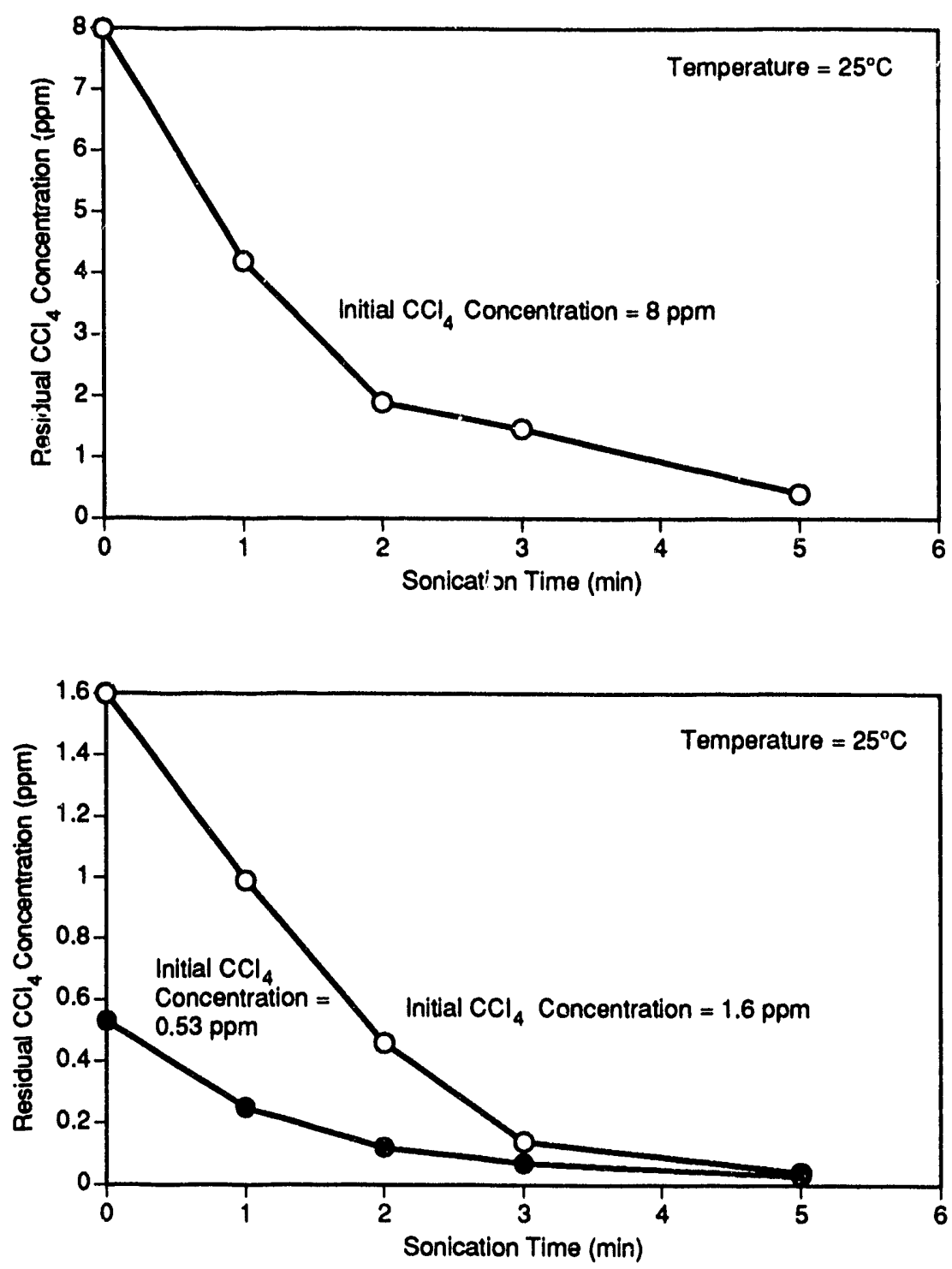

FIGURE 3.4 Decreases in $\mathrm{CCl}_{4}$ Concentration vs. Sonication

Period at $\mathrm{CCl}_{4}$ Concentrations of $8 \mathrm{ppm}, 1.6 \mathrm{ppm}$, and $0.53 \mathrm{ppm}$ 


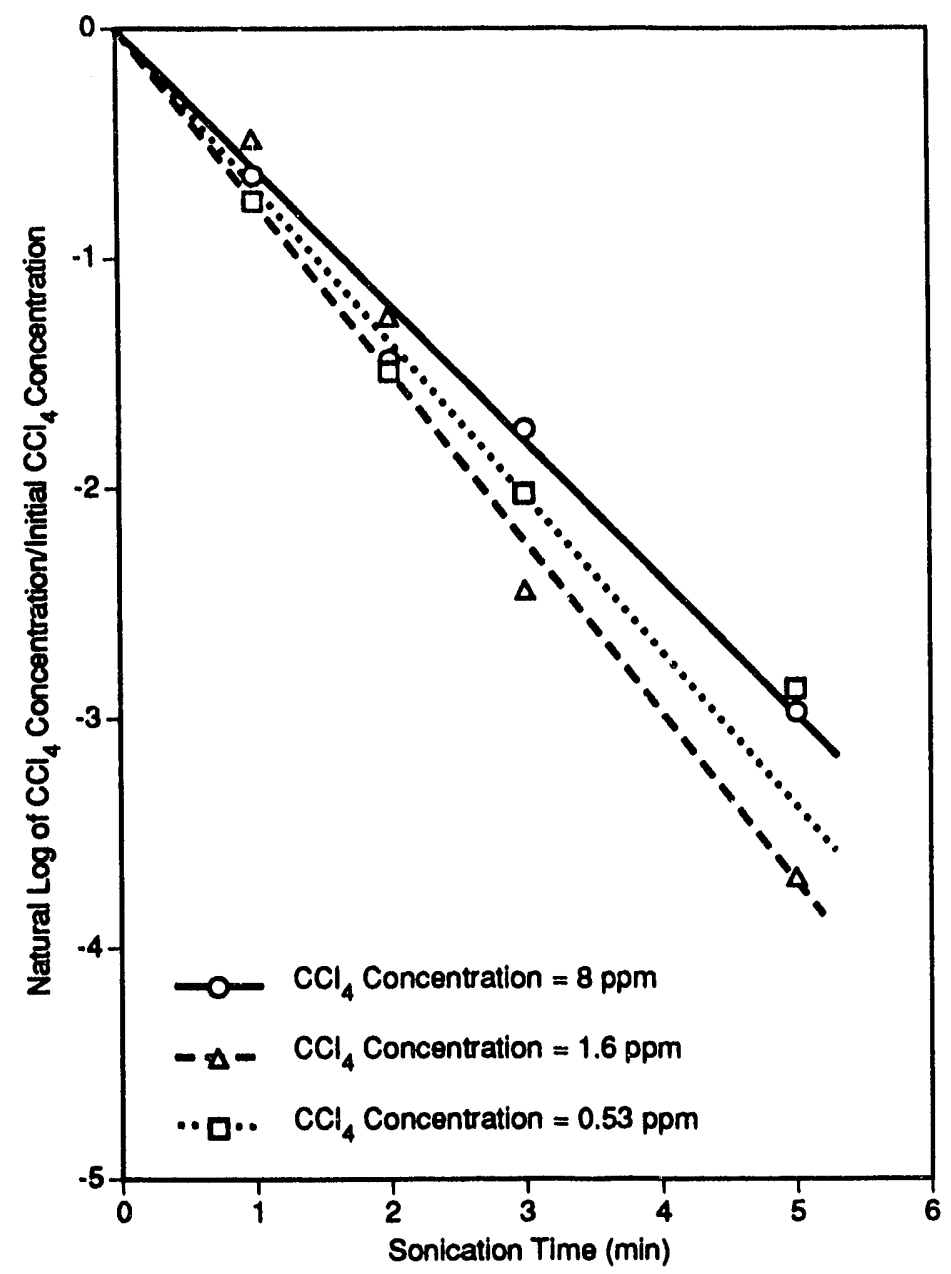

FIGURE 3.5 First-Order Plot of Natural Log of $\mathrm{CCl}_{4}$ Concentration vs. Sonication Period 


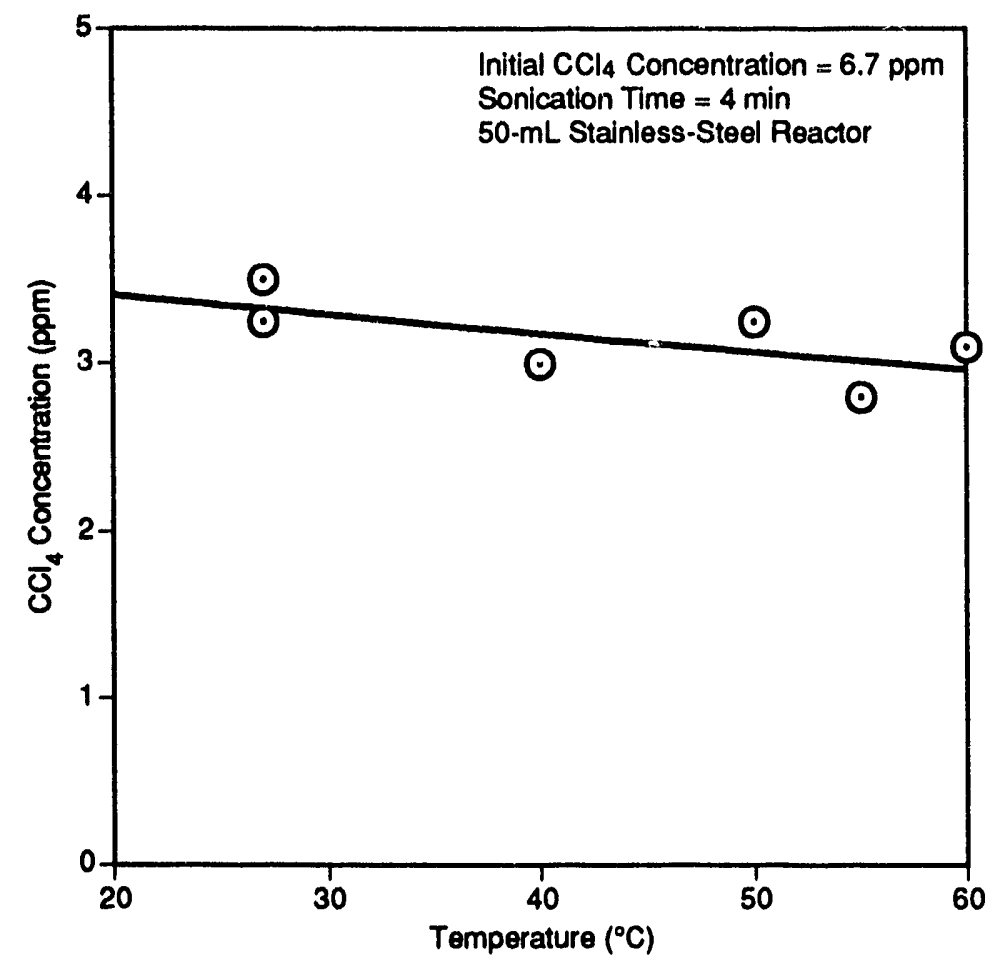

FIGURE 3.6 Effect of Steady-State Temperature on $\mathrm{CCl}_{4}$ Sonication

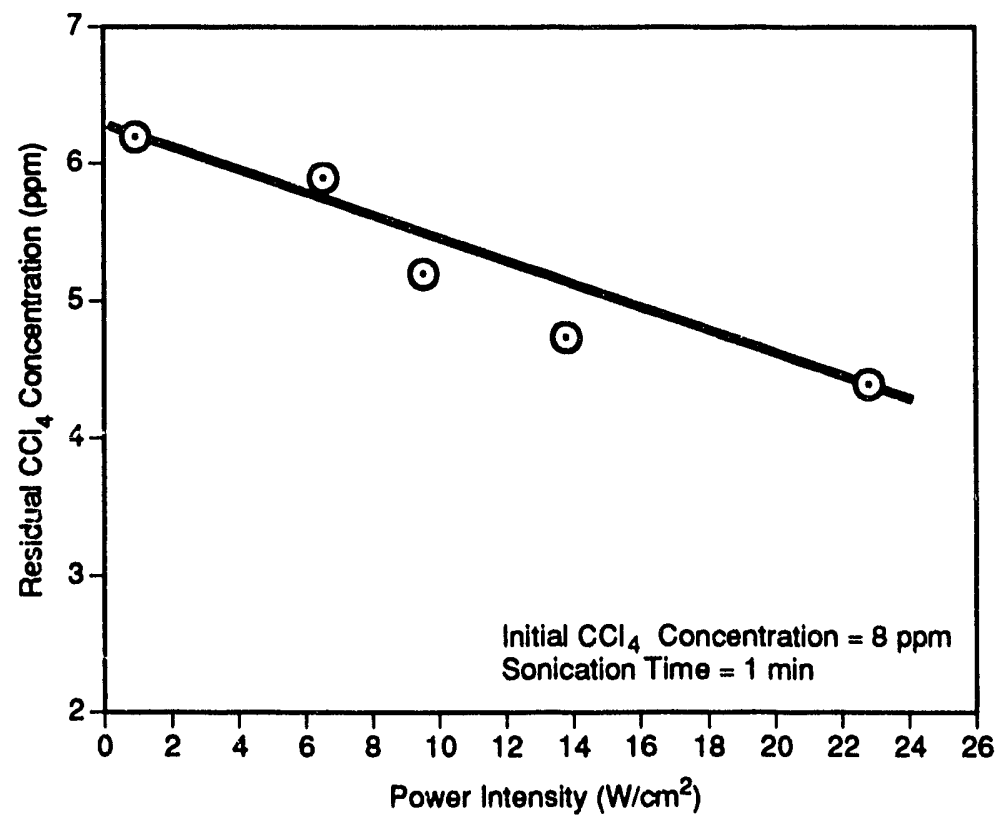

FIGURE 3.7 Effect of Power Intensity on $\mathrm{CCl}_{4}$ Sonication 


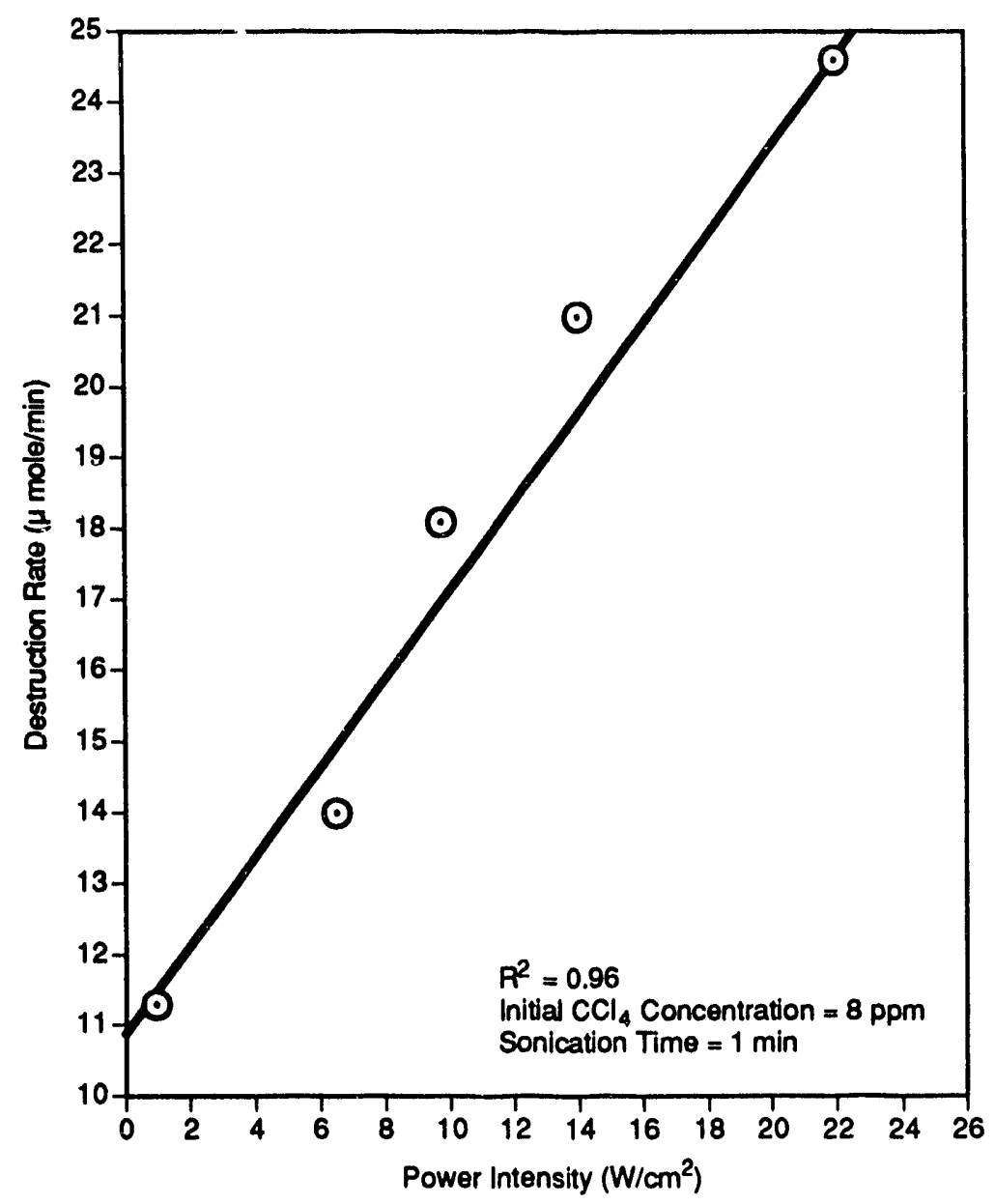

FIGURE 3.8 Dependence of $\mathrm{CCl}_{4}$ Destruction Rate on Power Intensity 


\subsection{Effect of Initial pH Value}

The relationship between initial $\mathrm{pH}$ value and $\mathrm{CCl}_{4}$ destruction is shown in Figure 3.9. Residual $\mathrm{CCl}_{4}$ decreases with increasing $\mathrm{pH}$ value between 3 and 9 for the same sonication period. Better sonication efficiency was observed at higher initial $\mathrm{pH}$ values; however, the rate of improvement diminished as the $\mathrm{pH}$ was raised above 6 . Because most of the irradiations were conducted at near neutral conditions for groundwater treatment, any variations in initial $\mathrm{pH}$ would have had a minimal effect on $\mathrm{CCl}_{4}$ destruction.

\subsection{Effect of Oxidant Addition}

Such oxidants as ozone and hydrogen peroxide have been widely used alone, in conjunction with suitable catalysts $\left(\mathrm{Fe}^{+2}\right.$ used in the Fenton reaction), or with ultraviolet (UV) light to effect the destruction of organic compounds in water. The oxidation intensities of different potential oxidants are given in Table 3.1. Of the oxidants listed, the hydroxyl radical $(\mathrm{OH})$ is the second-strongest oxidant. Hydrogen peroxide was added to the irradiated water samples to study the effect of an oxidant in an ultrasonic field. With sonication, $\mathrm{H}_{2} \mathrm{O}_{2}$ is known to decompose in the cavities to yield $\mathrm{OH}$ radicals. The radicals diffuse into the bulk liquid and increase the radical concentrations in the solution, thus enhancing the destruction rate of organic compounds.

Figure 3.10 shows $\mathrm{CCl}_{4}$ destruction versus $\mathrm{H}_{2} \mathrm{O}_{2}$ dosages (as a $\left[\mathrm{H}_{2} \mathrm{O}_{2}\right] /\left[\mathrm{CCl}_{4}\right]$ ratio) after 2 min of irradiation. Initial $\mathrm{CCl}_{4}$ concentrations as high as $6.5 \mathrm{ppm}$ were reduced to approximately $0.9 \mathrm{ppm}$ without the addition of any oxidant. As the $\mathrm{H}_{2} \mathrm{O}_{2}$ dosage was increased to 20:1, the $\mathrm{CCl}_{4}$ concentration slowly decreased to about $0.7 \mathrm{ppm}$. This decrease is insignificant when compared with the addition of $\mathrm{H}_{2} \mathrm{O}_{2}$ dosages. Figure 3.11 shows $\mathrm{CCl}_{4}$ destruction versus time with the addition of only $\mathrm{H}_{2} \mathrm{O}_{2}$ and without ultrasonics. Only slightly decreasing amounts of $\mathrm{CCl}_{4}$ were observed after a reaction time of $60 \mathrm{~min}$, and the effect was negligible.

These results illustrate that the addition of the $\mathrm{H}_{2} \mathrm{O}_{2}$ oxidant has a small effect on the $\mathrm{CCl}_{4}$ destruction rate, either with or without ultrasonics. This phenomenon can be explained by comparing the $\mathrm{CCl}_{4}$ reaction-rate constants between the bulk-liquid phase (less than $10^{7} \mathrm{M}^{-1} \mathrm{~min}^{-1}$ ) and the cavities (around $10^{12} \mathrm{M}^{-1} \mathrm{~min}^{-1}$ ). The $\mathrm{CCl}_{4}$ is relatively inactive to radicals because all of the four free electrons are captured by chloride ions and form only single bonds $(\mathrm{C}-\mathrm{Cl})$ in the molecule. However, the single bond between $\mathrm{C}$ and $\mathrm{Cl}$ provides low dissociation energy (only about $80 \mathrm{kcal} / \mathrm{mole}$ ), thus making it easier for the bonds to cleave in the carities. Therefore, the bulk-liquid reaction-rate constant for $\mathrm{CCl}_{4}$ is about five orders of magnitude lower than that in the cavities. This difference makes the reactions in the cavities predominant; therefore, the addition of oxidants has only a minimal effect on the whole system.

For other organic compounds (such as TCE and benzene), the double bonds between the two atomic carbons $(\mathrm{C}=\mathrm{C})$ are electron-dense, thus yielding much higher reaction-rate constants with the hydroxyl radicals (as compared with the single $\mathrm{C}-\mathrm{C}$ bond in saturated hydrocarbons, such 
as $\mathrm{CCl}_{4}$ ). Consequently, under ultrasonic irradiation, the addition of $\mathrm{H}_{2} \mathrm{O}_{2}$ into water containing TCE or other unsaturated hydrocarbons may result in a substantial increase in the destruction rate.

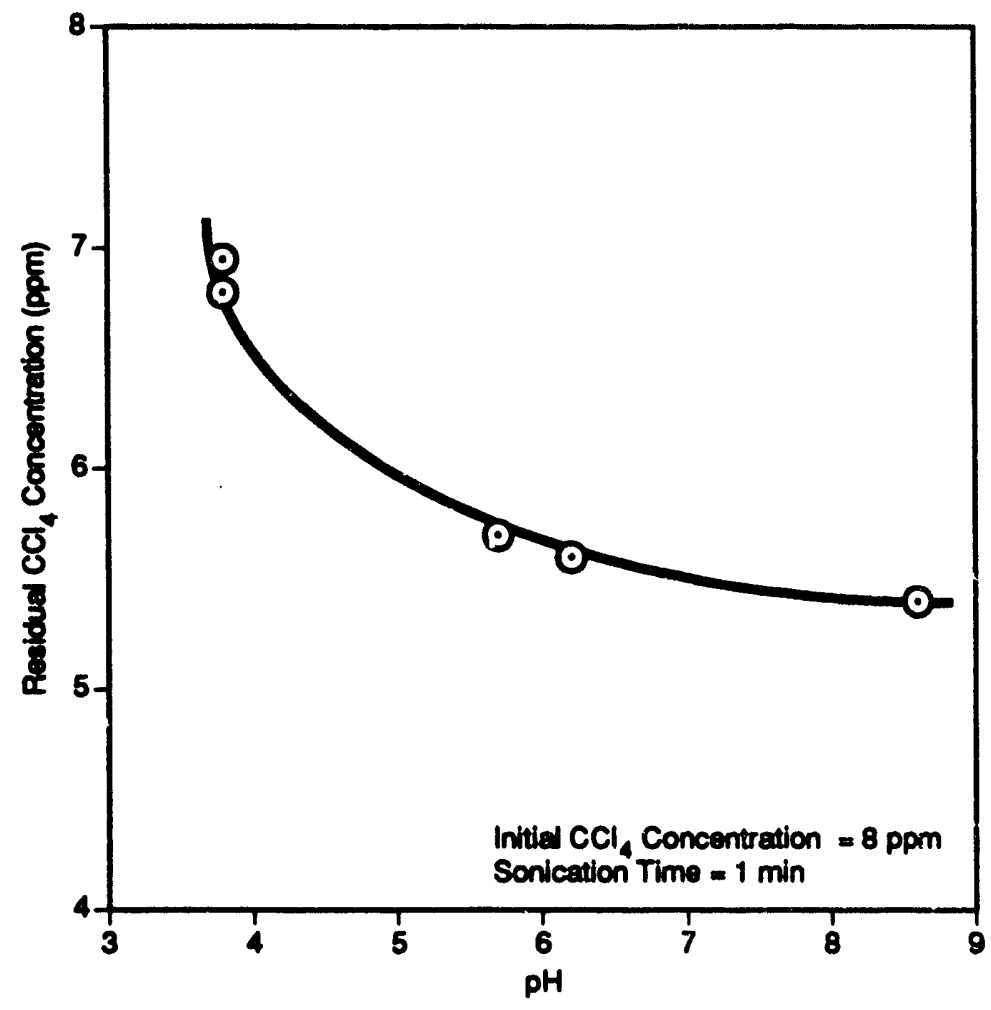

FIGURE 3.9 Effect of Initial pH Value on $\mathrm{CCl}_{4}$ Sonication 
TABLE 3.1 Oxidation Potential and Relative

Oxidation Power of Hydroxyl Radical and

Other Oxidants

\begin{tabular}{lll}
\hline \multicolumn{1}{c}{ Oxidants } & $\begin{array}{c}\text { Oxidation } \\
\text { Potential } \\
\text { (V) }\end{array}$ & $\begin{array}{c}\text { Relative } \\
\text { Oxidation } \\
\text { Powera }\end{array}$ \\
\hline Fluorine & & \\
Hydroxyl radical & 3.06 & 2.25 \\
Atomic oxygen & 2.8 & 2.06 \\
Ozone & 2.42 & 1.78 \\
Chlorine dioxide & 2.07 & 1.52 \\
Hydrogen peroxide & 1.96 & 1.44 \\
Perhydroxyl radicals & 1.77 & 1.31 \\
Permanganate & 1.70 & 1.25 \\
Hypobromous acid & 1.67 & 1.24 \\
Hypochlorous acid & 1.59 & 1.17 \\
Chlorine & 1.49 & 1.10 \\
Bromine & 1.36 & 1.00 \\
lodine & 1.10 & 0.80 \\
& 0.73 & 0.54 \\
\hline
\end{tabular}

a Based on chlorine as reference $(=1.00)$.

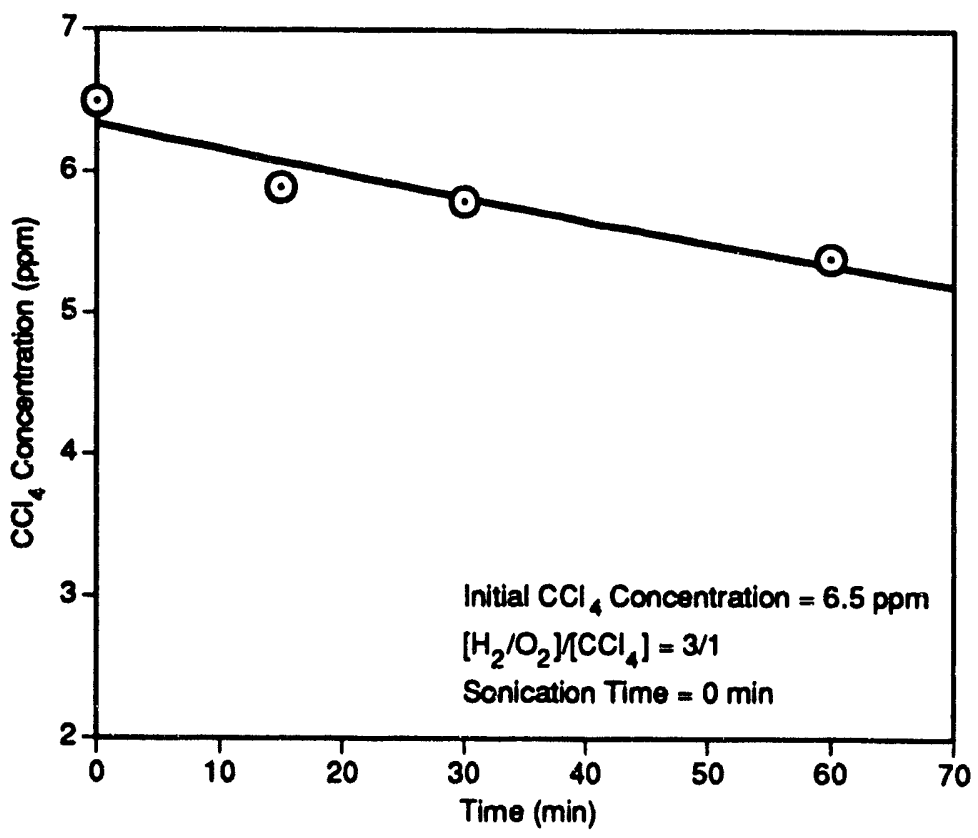

FIGURE 3.10 Effect of $\mathrm{H}_{2} \mathrm{O}_{2}$ Dosage on $\mathrm{CCl}_{4}$ Sonication 


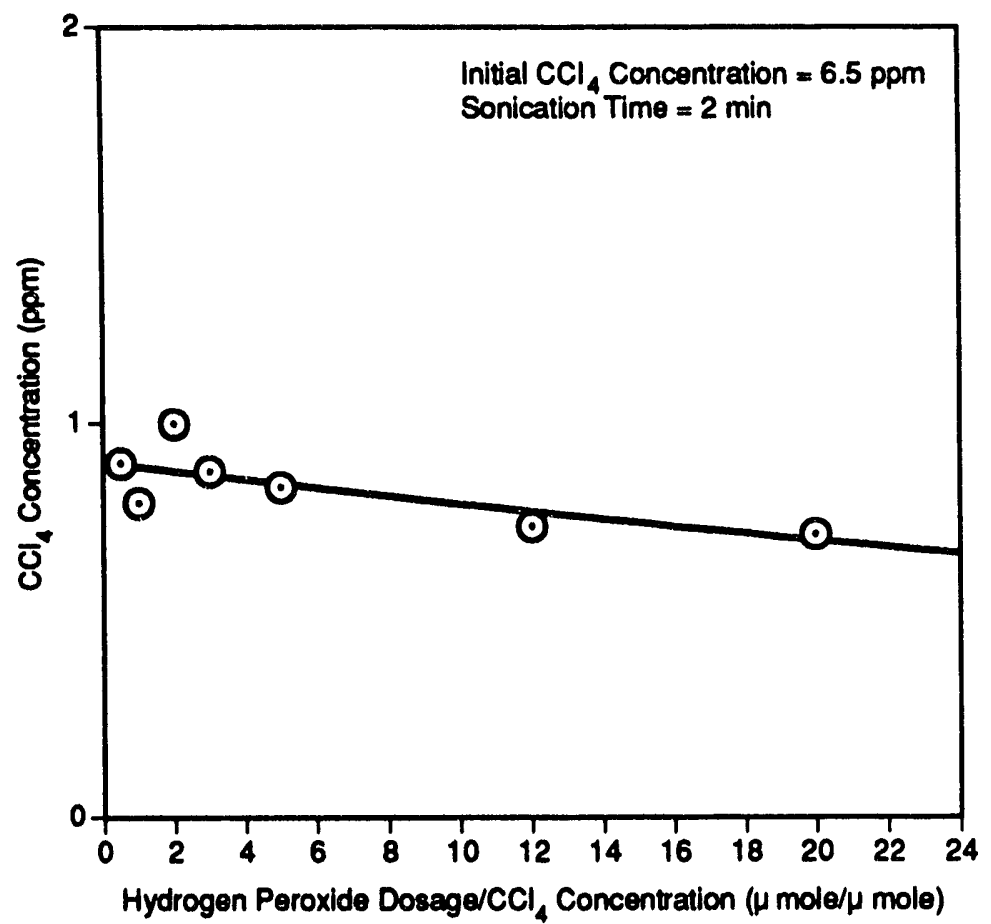

FIGURE 3.11 Effect of $\mathrm{H}_{2} \mathrm{O}_{2}$ Dosage on $\mathrm{CCl}_{4}$ with No Sonication 


\section{Development of Reaction Model}

\subsection{Detalled Chemical Mechanism}

The modeling of chemical kinetics with a large set of elementary reactions is a valuable tool in the analysis of the complex processes that underlie the phenomena of combustion or pyrolysis. The increasing availability of fundamental rate-constant data (Margulis and Didenko 1984), the development of computational methods for solving large systems of "stiff" differential equations, and the phenomenal growth in the power and availability of desk-top computers have spurred the increased application of detailed kinetic modeling. A model of this kind - after being validated by experimental results - could be a valuable predictive tool for exploring measures to improve complex chemical processes.

Detailed kinetic modeling is typically accomplished by assembling a multistep mechanism of elementary reactions with the fundamental thermochemical and rate constants that describe these elementary reactions. This information is thus transformed into a set of differential equations that describe the time variance of species concentrations. With the starting concentrations specified, the set of differential equations can readily be solved analytically or numerically.

The chemical mechanism presented in Table 4.1 was developed by systematically considering the major plausible elementary reactions of water, dissolved air (nitrogen and oxygen), organic compounds $\left(\mathrm{CCl}_{4}\right)$, and their related reactions in the ultrasonic field (DOC 1972; Glaze and Kang 1989; Margulis 1974). The reaction numbers specified in the text correspond to those provided in Table 4.1. The symbol ")))" in reactions $1,11,19$, and 28 represents ultrasonic irradiation. The reactions are initiated by the dissociation of water molecules in the cavitation holes (reaction 1). Atomic hydrogen $(\mathrm{H})$ and hydroxyl radicals $(\mathrm{OH})$ are formed as a result of this reaction. These radicals recombine to form water or hydrogen molecules $\left(\mathrm{H}_{2}\right)$ or react with oxygen molecules $\left(\mathrm{O}_{2}\right)$ to yield hydroperoxide radicals $\left(\mathrm{HO}_{2}\right)$ and $\mathrm{H}_{2} \mathrm{O}_{2}$ (reactions 2-6). The radicals further react with the $\mathrm{H}_{2} \mathrm{O}_{2}$ produced in the reactions to form $\mathrm{H}_{2}$ molecules, water, and other radicals (reactions 7-10). To simplify the treatment, we will not consider the secondary reactions of $\mathrm{H}$ and $\mathrm{OH}$ with the $\mathrm{H}_{2} \mathrm{O}_{2}$ that is formed in the process.

In the presence of dissolved nitrogen, nitrogen molecules $\left(\mathrm{N}_{2}\right)$ decompose in the cavitation holes (reaction 11) to form atomic nitrogen (N). After a series of reactions, $\mathrm{N}$ reacts with the $\mathrm{OH}$ radicals produced from the dissociation of water and related reactions to yield nitrate and nitrite (reactions 12-15). Atomic nitrogen also reacts with $\mathrm{H}$ and $\mathrm{O}_{2}$ molecules to regenerate $\mathrm{N}_{2}$ and $\mathrm{H}_{2}$ molecules and produce nitric oxide $(\mathrm{NO})$ and $\mathrm{O}_{2}$ radicals (reactions $16-18$ ).

Oxygen molecules dissolved in the water also decompose in the cavitation holes (reaction 19) to produce atomic oxygen $(O)$ and compete with reaction 2 , leading to the formation of hydroxyl radicals (reaction 20). Atomic oxygen then reacts with $\mathrm{H}_{2}$ molecules, $\mathrm{H}_{2} \mathrm{O}_{2}$, and $\mathrm{HO}_{2}$ to form $\mathrm{O}_{2}$ molecules and other radicals, such as $\mathrm{H}$ and $\mathrm{OH}$ (reactions 21-23). 
The target contaminant, $\mathrm{CCl}_{4}$, present in the water is either directly decomposed in the cavities (reaction 28 ) or oxidized by radicals (reactions 24-27). If the reaction does not proceed to completion, the final products of the irradiation of $\mathrm{CCl}_{4}$ by ultrasound would include water, carbon dioxide and/or some other intermediate chemical compounds.

\subsection{Development of Mathematical Model}

On the basis of the chemical-kinetic mechanism proposed above, the primary reaction pathway appears to be thermal dissociation in the cavities, such as those represented in reactions 1 , 11,19 , and 28 . The high temperature and the high pressure in the cavities provide the activity energy required for bond cleavage. Water, nitrogen, oxygen, and carbon tetrachloride molecules decompose in these cavities to directly form the radicals. The radicals then either react with each other to form new molecules and radicals or diffuse into the bulk liquid to serve as oxidants. The secondary reaction seems to be in the bulk-liquid phase, during which oxidants (such as the $\mathrm{H}$ and $\mathrm{OH}$ radicals generated in the cavities) oxidize $\mathrm{CCl}_{4}$ and other molecules.

To better clarify these reactions, the whole process can be divided into two major areas: (1) the cavities, within which temperature and pressure are extremely high and the molecule vapors reach supercritical conditions and decompose, and (2) the bulk-liquid phase, where under normal operating temperatures and pressures, the radicals oxidize the molecules to form new products. In a batch reactor with reactions occurring in the bulk-liquid phase, we assume a second-order rate constant, whereby the destruction rate of $\mathrm{CCl}_{4}$ can be represented by the following equation (the general second-order reaction-rate formula):
TABLE 4.1 Proposed ChemicalKinetic Mechanism

A. Water Dissociation:

$$
\begin{aligned}
\text { 1. } & \left.\left.\mathrm{H}_{2} \mathrm{O} \rightarrow I\right)\right) \mathrm{H}+\mathrm{OH} \\
\text { 2. } & \mathrm{H}+\mathrm{H} \rightarrow \mathrm{H}_{2} \\
\text { 3. } & \mathrm{H}+\mathrm{O}_{2} \rightarrow \mathrm{HO}_{2} \\
\text { 4. } & \mathrm{HO}_{2}+\mathrm{HO}_{2} \rightarrow \mathrm{H}_{2} \mathrm{O}_{2}+\mathrm{O}_{2} \\
\text { 5. } & \mathrm{OH}+\mathrm{OH} \rightarrow \mathrm{H}_{2} \mathrm{O}_{2} \\
\text { 6. } & \mathrm{H}+\mathrm{OH} \rightarrow \mathrm{H}_{2} \mathrm{O} \\
\text { 7. } & \mathrm{H}+\mathrm{H}_{2} \mathrm{O}_{2} \rightarrow \mathrm{OH}+\mathrm{H}_{2} \mathrm{O} \\
\text { 8. } & \mathrm{H}+\mathrm{H}_{2} \mathrm{O}_{2} \rightarrow \mathrm{H}_{2}+\mathrm{HO}_{2} \\
\text { 9. } & \mathrm{OH}+\mathrm{H}_{2} \mathrm{O}_{2} \rightarrow \mathrm{HO}_{2}+\mathrm{H}_{2} \mathrm{O} \\
\text { 10. } & \mathrm{OH}+\mathrm{H}_{2} \rightarrow \mathrm{H}_{2} \mathrm{O}+\mathrm{H}
\end{aligned}
$$

B. In the Presence of Nitrogen:

$$
\begin{array}{ll}
\text { 11. } & \mathrm{N} \rightarrow \rightarrow) l 2 \mathrm{~N} \\
\text { 12. } & \mathrm{N}+\mathrm{OH} \rightarrow \mathrm{NO}+\mathrm{H} \\
\text { 13. } & \mathrm{NO}+\mathrm{OH} \rightarrow \mathrm{HNO}_{2} \\
\text { 14. } & \mathrm{NO}+\mathrm{OH} \rightarrow \mathrm{NO}_{2}+\mathrm{H} \\
\text { 15. } & 2 \mathrm{NO}_{2}+\mathrm{H}_{2} \mathrm{O}_{2} \rightarrow \mathrm{HNO}_{2}+\mathrm{HNO}_{3} \\
\text { 16. } & \mathrm{N}+\mathrm{H} \rightarrow \mathrm{NH} \\
\text { 17. } & \mathrm{NH}+\mathrm{NH} \rightarrow \mathrm{N}_{2}+\mathrm{H}_{2} \\
\text { 18. } & \mathrm{N}+\mathrm{O}_{2} \rightarrow \mathrm{NO}+\mathrm{O}
\end{array}
$$

C. In the Presence of Oxygen:
19. $\left.\mathrm{O}_{2} \rightarrow()\right) 2 \mathrm{O}$
20. $\mathrm{H}+\mathrm{O}_{2} \rightarrow \mathrm{OH}+\mathrm{O}$
21. $\mathrm{O}+\mathrm{H}_{2} \rightarrow \mathrm{OH}+\mathrm{H}$
22. $\mathrm{O}+\mathrm{HO}_{2} \rightarrow \mathrm{OH}+\mathrm{O}_{2}$
23. $\mathrm{O}+\mathrm{H}_{2} \mathrm{O}_{2} \rightarrow \mathrm{OH}+\mathrm{HO}_{2}$

D. In the Presence of Organic Compounds $\left(\mathrm{CCl}_{4}\right)$ :
24. $\mathrm{CCl}_{4}+\mathrm{OH} \rightarrow$ products
25. $\mathrm{CCl}_{4}+\mathrm{H} \rightarrow$ products
26. $\mathrm{CCl}_{4}+\mathrm{HO}_{2} \rightarrow$ products
27. $\mathrm{CCl}_{4}+\mathrm{O} \rightarrow$ products
28. $\left.\mathrm{CCl}_{4} \rightarrow \|\right)$ products 


$$
\begin{aligned}
-\mathrm{d}\left[\mathrm{CCl}_{4}\right] / \mathrm{dt} & =\mathrm{k}_{\text {liquid }}=\mathrm{k}_{24}[\mathrm{OH}]\left[\mathrm{CCl}_{4}\right]+\mathrm{k}_{25}[\mathrm{H}]\left[\mathrm{CCl}_{4}\right]+\mathrm{k}_{26}\left[\mathrm{HO}_{2}\right]\left[\mathrm{CCl}_{4}\right] \\
& +\mathrm{k}_{27}[\mathrm{O}]\left[\mathrm{CCl}_{4}\right]
\end{aligned}
$$

The total disappearance rate of $\mathrm{CCl}_{4}$ equals the accumulated rate of all of the related reactions in the mechanism. If the reaction takes place in the cavities, it is again reasonable to assume a secondorder rate constant. In this case, the destruction rate of $\mathrm{CCl}_{4}$ can also be expressed by a similar rate formula:

$$
-\mathrm{d}\left[\mathrm{CCl}_{4}\right] / \mathrm{dt}=\mathrm{k}_{\text {cavity }}=\mathrm{k}_{\mathrm{c}} \times \mathrm{k}_{28}\left[\mathrm{CCl}_{4}\right][\mathrm{M}]
$$

where $M$ is any collision partner and $k_{c}$ is the system adjustment coefficient, which is, for example, a function of cavity concentration, cavity radius, and mixing extent of the system. This coefficient is assumed to be a constant if all of the experimental conditions (such as reaction vessel size, steady-state temperature, and power intensity) are unchanged. The coefficient can be obtained by a best fit of the experimental data to the model. Because the reaction occurs in the cavity, $\left[\mathrm{CCl}_{4}\right]$ in the $\mathrm{k}_{\text {cavity }}$ formula represents the concentration of $\mathrm{CCl}_{4}$ in the vapor phase. If we assume an ideal gas and Rault's law to be valid in this case, this value can be calculated by applying Henry's law.

In addition to $\mathrm{CCl}_{4}$, the net reaction rates for all the other compounds in the process can be expressed in similar rate formulas, or differential equations, that describe the decreasing or increasing concentrations in the ultrasonic field. If all of the reaction-rate constants are available, the differential equations can be solved simultaneously to obtain the individual concentration profile for each species as a function of irradiation time.

\subsection{Computer Simulation and Results}

Computer simulation of ultrasonic chemical kinetics was carried out on the basis of the proposed mechanism described above. With second-order reactions, the reaction-rate constants in the model were obtained either from published data (reactions 1 to 27 [Margulis and Didenko 1984; Tsang amd Hampson 1986; Baulch et al. 1981; Johnston 1966]) or from experiments (reaction 28). Once determined, these constants cannot be used as variables; therefore, no adjustable parameters are included in the model. Reverse reactions were not considered significant because (1) no other chemicals have been added in the experiments so far and (2) the concentrations of the products for each reaction were assumed to be much less than those of the reactants.

All of the elementary reactions proposed in the mechanism were transformed into a set of differential equations that describes the time variance of species concentrations on the basis of the rate formulas $\mathrm{k}_{\text {liquid }}$ and $\mathrm{k}_{\text {cavity, }}$, depending on whether these reactions take place in the bulk-liquid phase or in the cavitation cavity. The $\mathrm{k}_{\mathrm{c}}$ value in the $\mathrm{k}_{\text {cavity }}$ equation was obtained by a best fit of the experimental data and was determined to be $2.5 \times 10^{-11}$ for this system. With the initial 
concentration specified, one can readily solve these equations. The results are shown in Figures 4.1 and 4.2. The results illustrate that the model fits the experimental data relatively well at low $\mathrm{CCl}_{4}$ concentrations (below $10 \mathrm{ppm}$ ). Correlation coefficients greater than 0.99 were obtained, although deviations were observed at higher $\mathrm{CCl}_{4}$ concentrations $(46.7 \mathrm{ppm})$. The predicted destruction rate was greater than that observed in the experiments, perhaps because the organic vapor pressure in the cavity increased with increasing $\mathrm{CCl}_{4}$ concentration; therefore, Henry's law may have no longer applied at that high concentration. In these cases, the activity for each compound in the cavity may need to be taken into consideration.
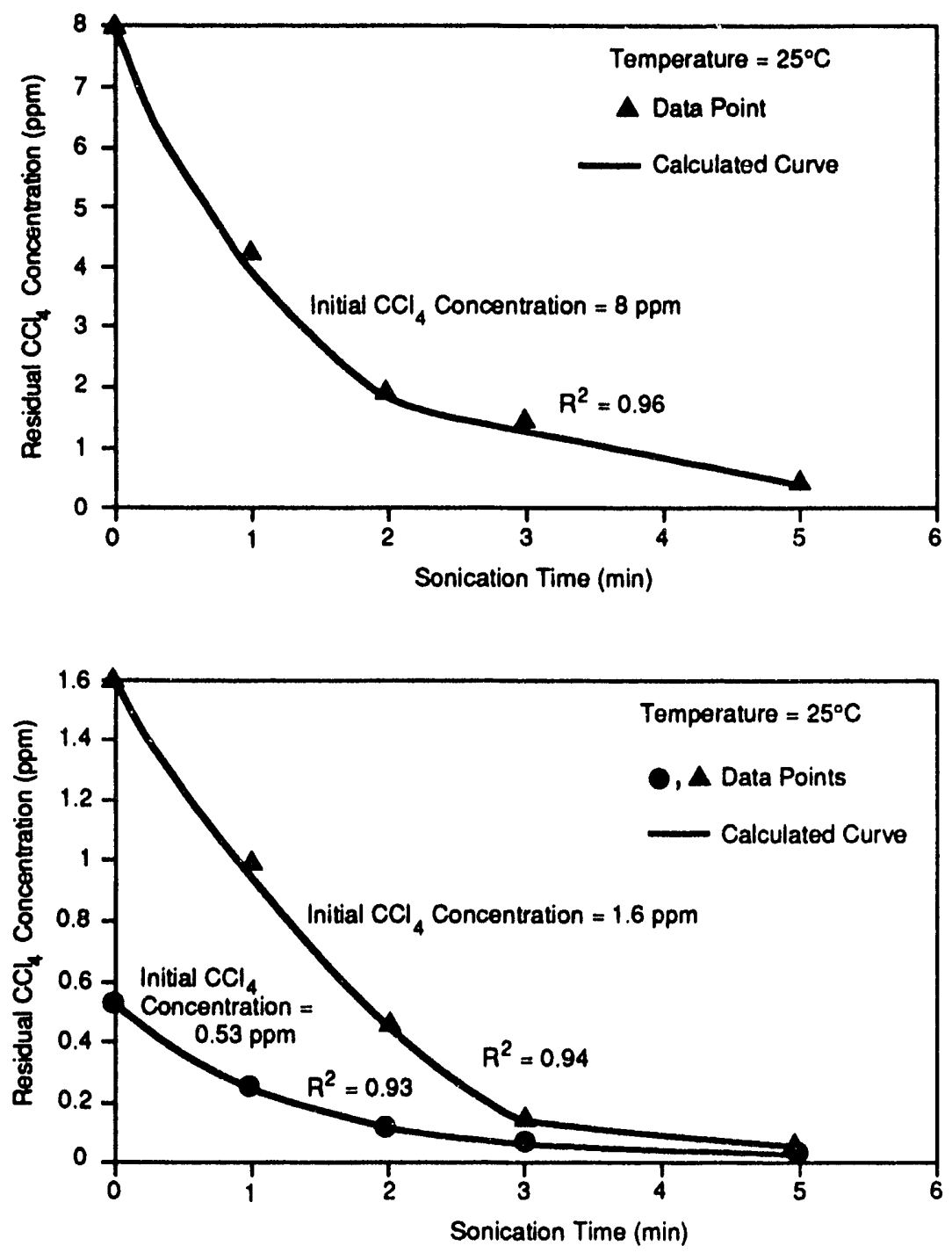

FIGURE 4.1 Experimental Data vs. Calculated Results of Model at $\mathrm{CCl}_{4}$ Concentrations of $8 \mathrm{ppm}$ and $1.6 \mathrm{ppm}$ 


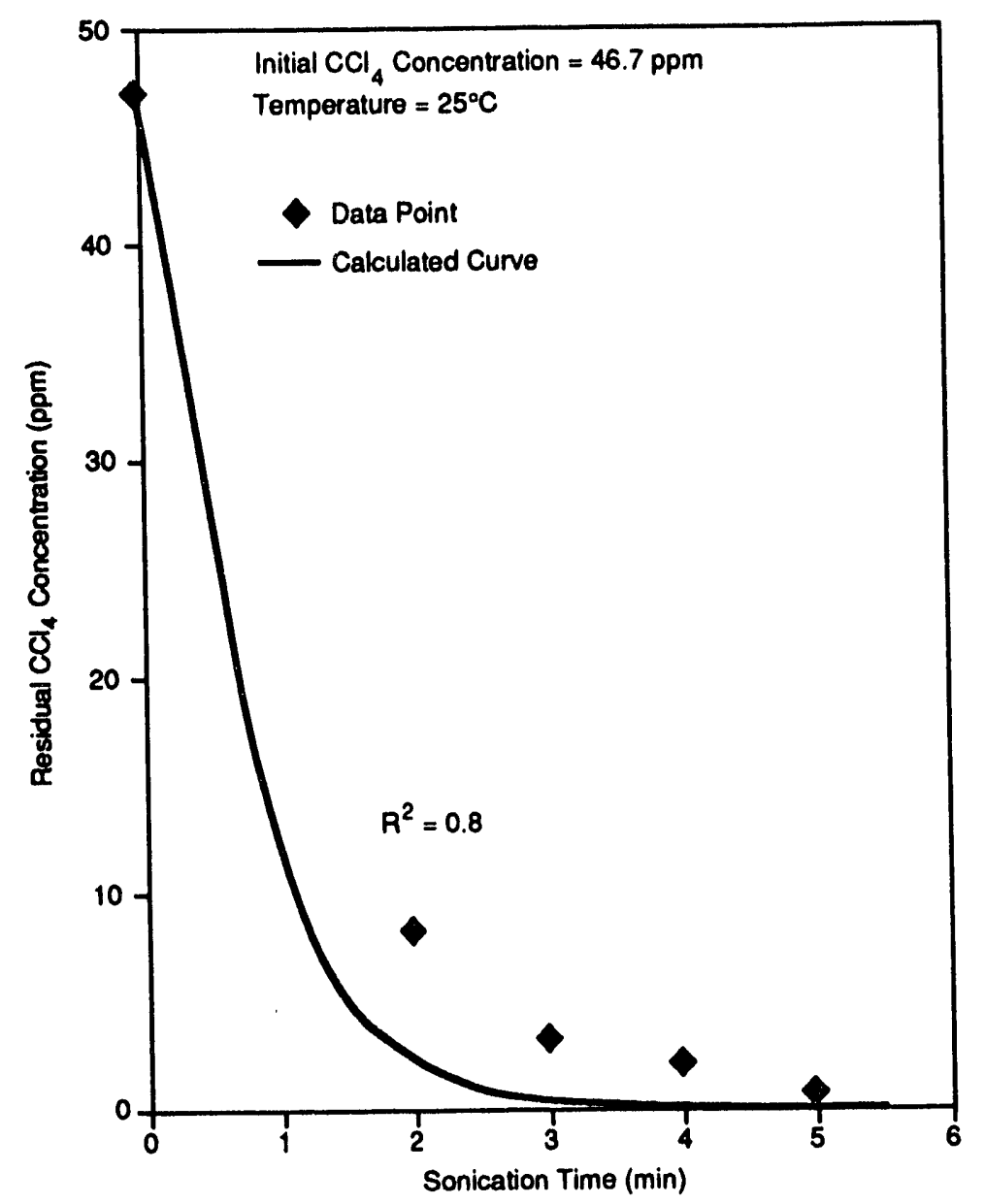

FIGURE 4.2 Experimental Data vs. Calculated Results of Model at a $\mathrm{CCl}_{4}$ Concentration of $47 \mathrm{ppm}$

The sensitivity of each reaction in the model was also tested. Results revealed that the concentration of dissolved nitrogen in the system has a minimal effect on the rate of $\mathrm{CCl}_{4}$ destruction, an effect that is neglected. The major reactions affecting the $\mathrm{CCl}_{4}$ destruction rate were found to be the dissociation of water molecules and the decomposition of $\mathrm{CCl}_{4}$ molecules in the cavity. In the bulk-liquid phase, the reaction between $\mathrm{OH}$ radicals and $\mathrm{CCl}_{4}$ predominated, followed by the reactions of the atomic hydrogen, atomic oxygen, and finally $\mathrm{HO}_{2}$ radicals. 


\section{Conclusions and Recommendations}

\subsection{Conclusions}

Initial experimental results from the first-year laboratory-research studies conducted at Argonne confirmed the feasibility of using the ultrasonic process for the destruction of low concentrations of $\mathrm{CCl}_{4}$ in water. Reduction efficiencies of greater than $99.5 \%$ were achieved following about eight minutes of irradiation. Subsequent experiments were then carried out to gain an improved understanding of the reaction kinetics of this process. On the basis of the results of these experiments, the following conclusions were drawn:

1. At low $\mathrm{CCl}_{4}$ concentrations (under $100 \mathrm{ppm}$ ) in water, the rate of $\mathrm{CCl}_{4}$ destruction was found to be first order with respect to $\mathrm{CCl}_{4}$ concentration.

2. The rate of $\mathrm{CCl}_{4}$ destruction was found to be strongly affecied by the intensity of the ultrasonic energy applied, with the destruction rate increasing proportionally to the intensity.

3. Other process parameters, such as temperature and initial $\mathrm{pH}$ value of the solution, were found, within the ranges investigated, to have little effect on $\mathrm{CCl}_{4}$ destruction rate.

4. The addition of small amounts of hydrogen peroxide to the solution had little effect on $\mathrm{CCl}_{4}$ destruction rate, suggesting that the destruction of $\mathrm{CCl}_{4}$ in water under ultrasonic irradiation is dominated by the high-temperature dissociation reactions within the collapsing cavities.

5. A detailed kinetic model of the destruction of $\mathrm{CCl}_{4}$ in water was developed; this model consists of a series of elementary reactions. The calculated results from the model agree reasonably well with the experimental results, suggesting that modeling could be a useful tool in the scaleup of the process.

\subsection{Recommendations}

To further develop and broaden the applicability of the ultrasonic detoxification process, the following research is recommended: 
1. Experimental studies on progressively larger continuous-flow systems should be undertaken to generate data and develop correlations/models that would be useful for the design of a commercial system.

2. Bench-scale experiments should be performed to investigate the effect of adding suitable catalysts, homogeneous and/or heterogeneous, on the enhancement of destruction rate under ultrasonic irradiation.

3. Experimenta! and modeling work should be undertaken on water samples containing other hazardous chlorinated and aromatic organic compounds, such as TCE and benzene.

4. Experimental and modeling studies should also be extended to other types of waste, including soils and mixed wastes. 


\section{References}

Baulch, D.L., et al., 1981, Evaluated Kinetic Data for High Temperature Reactions, J. Physical and Chemical Reference Data, 10(1):649-715.

Chen, J.W., and W.M. Kalback, 1967, Industrial and Engineering Chemistry, Fundamentals, 6:175.

Chen, J.W., J.A. Chang, and G.V. Smith, 1969, Chemical Engineering Progress Symposium Series, 109(67):18.

DOC, 1972, Rate Constants of Gas Phase Reactions, U.S. Department of Commerce (DOC), National Bureau of Standards, COM-72-10014.

EPA, 1990, The Superfund Innovative Technology Evaluation Program: Technology Profiles, U.S. Environmental Protection Agency Report EPA/540/5-90/006, Nov.

Federal Register, 1979, Vol. 44, no. 233, Dec. 3.

Fogler, H.S. and D. Bames, 1968, Industrial and Engineering Chemistry, Fundamentals, 7:222.

Glaze, W.H., and J. Kang, 1989, Industrial and Engineering Chemistry, Research, 28:15731580.

Johnston, H.S., 1966, Gas Phase Reaction Rate Theory, Ronald Press Company, New York.

Margulis, M.A., 1974, Russian J. of Physical Chemistry, 48(11):1653.

Margulis, M.A., and Y.T. Didenko, 1984, Russian J. of Physical Chemistry, 58(6):848.

Mason, T.J., 1990, Chemistry with Ultrasound, published for the Society of Chemical Industry, Elsevier Science Publishers Ltd., England.

Rozenberg, L.D., 1965, Soviet Physics, Acoustics, 11(1):110.

Suslick, K.S., 1989, The Chemical Effects of Ultrasound, Scientific American, pp. 80-86, Feb.

Suslick, K.S., 1990, Sonochemistry, Science, 247:1347-1520, March 23. 
Suslick, K.S., ed., 1988, Ultrasound: Its Chemical, Physical, and Biological Effects, VCH Publishers, Inc., New York.

Tsang, W., and R.F. Hampson, 1986, Chemical Kinetic Data Base for Combustion Chemistry, J. Physical and Chemical Reference Data, 15(3):1087-1279. 


\section{Appendix: Procedures for Starting Up and Shutting Down an Experiment}

Startup:

1. Check the hood for proper air flow: $\geq 170 \mathrm{ft} / \mathrm{min}$ face velocity.

2. Turn on the water circulator pump.

3. Select the desired cooling-water temperature.

4. Turn on the temperature readout and monitor the rising temperature until the desired temperature is attained and remains unchanged. (Note: The heater should automatically turn off after the cooling water reaches the selected temperature.)

5. Turn on the ultrasonic power supply and allow the system to warm up for $30 \mathrm{~min}$.

6. Check the power supply and the converter/probe to see if they are properly assembled.

7. Tune-up the power supply to get optimal performance.

8. Select the proper duty cycle.

9. Adjust the output control.

10. Select the desired sonication time.

11. Conduct one test run with all the selected settings by using deionized water as the sample solution.

12. Start the experiment.

Shutdown:

1. Turn off the ultrasonic power supply.

2. After the temperature of the cooling water returns to room temperature, turn off the circulator pump.

3. Drain the cooling water.

4. Turn off the temperature readout.

5. Close the hood. 

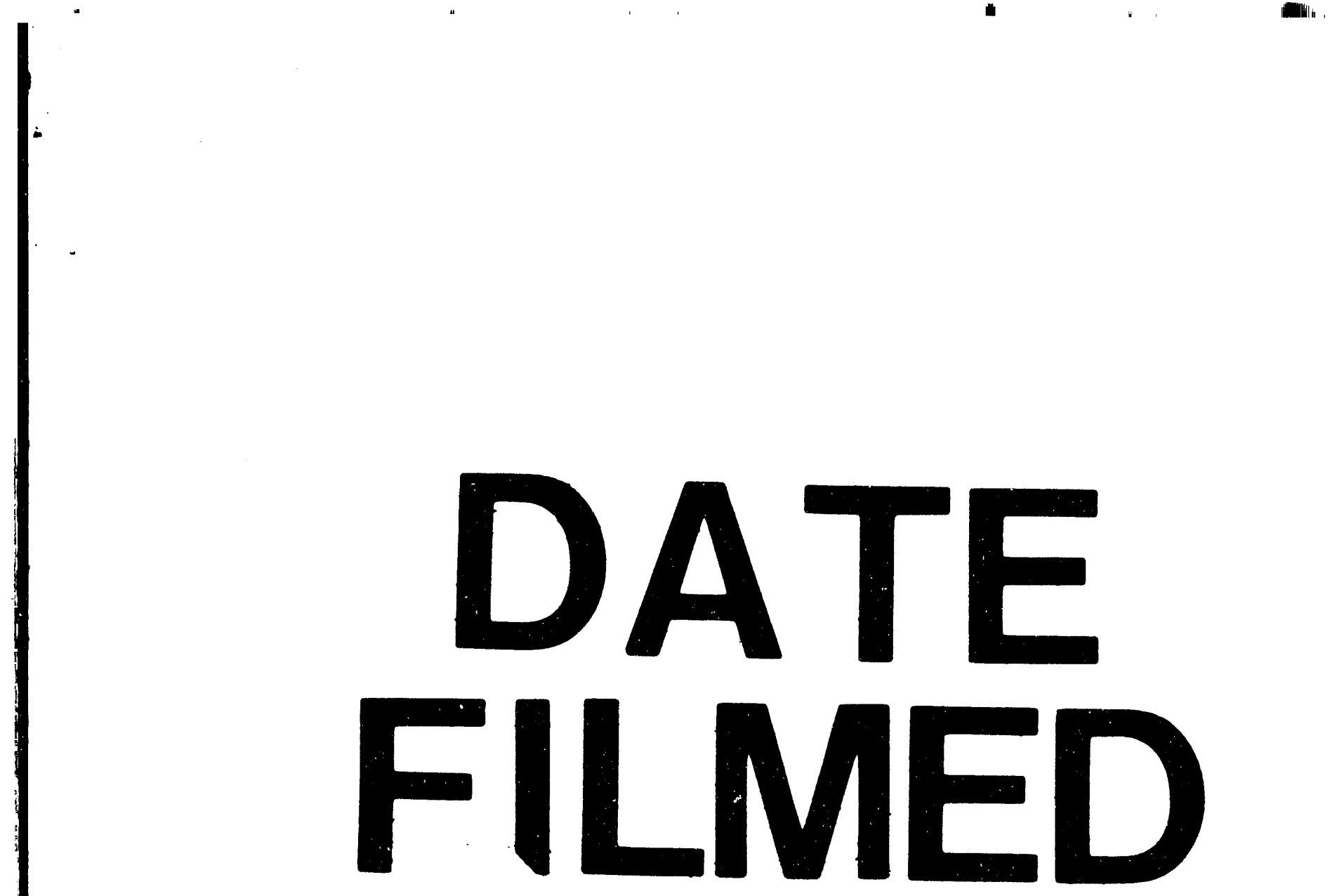

$121 / 8 / 92$ 
